\title{
Do Freshwater Fish Eat Microplastics? A Review with A Focus on Effects on Fish Health and Predictive Traits of MPs Ingestion
}

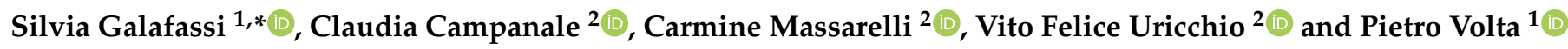 \\ 1 CNR Water Research Institute, L.go Tonolli 50, 28922 Verbania, Italy; pietro.volta@cnr.it \\ 2 CNR Water Research Institute, V.le F. De Blasio 5, 70132 Bari, Italy; claudia.campanale@ba.irsa.cnr.it (C.C.); \\ carmine.massarelli@ba.irsa.cnr.it (C.M.); vito.uricchio@ba.irsa.cnr.it (V.F.U.) \\ * Correspondence: silvia.galafassi@cnr.it
}

check for

updates

Citation: Galafassi, S.; Campanale, C.; Massarelli, C.; Uricchio, V.F.; Volta, P. Do Freshwater Fish Eat

Microplastics? A Review with A

Focus on Effects on Fish Health and Predictive Traits of MPs Ingestion. Water 2021, 13, 2214. https:// doi.org/10.3390/w13162214

Academic Editor: Heiko

L. Schoenfuss

Received: 24 June 2021

Accepted: 12 August 2021

Published: 14 August 2021

Publisher's Note: MDPI stays neutral with regard to jurisdictional claims in published maps and institutional affiliations.

Copyright: (C) 2021 by the authors. Licensee MDPI, Basel, Switzerland. This article is an open access article distributed under the terms and conditions of the Creative Commons Attribution (CC BY) license (https:/ / creativecommons.org/licenses/by/ $4.0 /)$.

\begin{abstract}
Microplastics (MPs) have received increasing attention in the last decade and are now considered among the most concerning emerging pollutants in natural environments. Here, the current knowledge on microplastic ingestion by wild freshwater fish is reviewed with a focus on the identification of possible factors leading to the ingestion of MPs and the consequences on fish health. Within the literature, 257 species of freshwater fishes from 32 countries have been documented to ingest MPs. MPs ingestion was found to increase with rising level of urbanization, although a direct correlation with MPs concentration in the surrounding water has not been identified. MPs ingestion was detected in all the published articles, with MPs presence in more than $50 \%$ of the specimens analyzed in one study out of two. Together with the digestive tract, MPs were also found in the gills, and there is evidence that MPs can translocate to different tissues of the organism. Strong evidence, therefore, exists that MPs may represent a serious risk for ecosystems, and are a direct danger for human health. Moreover, toxicological effects have also been highlighted in wild catches, demonstrating the importance of this problem and suggesting the need for laboratory experiments more representative of the environmental situation.
\end{abstract}

Keywords: plastic pollution; microplastic ingestion; trophic transfer; food webs

\section{Introduction}

The high level of the worldwide production of synthetic polymers [1] and the widespread presence of their products in everyday life had made plastic the most abundant man-made product in the environment. The first alarming reports of plastic pollution aroused during the 1970s in the Sargasso sea [2], in coastal water around England [3], and the Northwest Atlantic [4]. In 1972, Carpenter and colleagues had already described the presence of different types of polystyrene spheres with an average diameter of $0.5 \mathrm{~mm}$, covered with bacterial biofilm and with polychlorinated biphenyls adsorbed from the seawater, actively ingested by several fish species [3]. Since then, the attention paid by the research community has increased exponentially, and currently, microplastic particles (namely, plastic particles with dimensions between $5 \mathrm{~mm}$ and $1 \mu \mathrm{m}$, hereafter abbreviated as MPs, [5]) are among the emerging pollutants which most alerts scientists, decision-makers, and public opinion. Seawater has received much more attention than freshwater [6,7] and other environmental compartments such as air and soil [8]. The plastic issue is explicitly addressed only in the European Marine Strategy Framework Directive (MSFD, [9]), but not in other directives, for example, the eight years older European Water Framework Directive (WFD, [10]). The higher attention posed on marine MPs is not due to the presence of higher concentrations in seawater in respect to other environments, as recently shown for freshwater and soil [11-13], and this increased attention has led to a better understanding of the MPs toxicity in aquatic ecosystems [14]. A comprehensive review of the literature relating to MPs pollution shows that fish are the most commonly studied group of organisms (38\%), especially within studies that assess ingestion in wild catches (27\%). Among the latter, marine species were predominant [6]. Furthermore, due to the capability 
of responding to anthropogenic and climatic pressures $[15,16]$ and their accumulation of pollutants [17-20], fish have been considered good bioindicators for water quality assessment for many decades [21-24] and are currently used in many European countries as an indicator taxon for the assessment of the ecological status of water bodies according to the WFD [16,24,25]. Together with their wide distribution and ecological importance [26,27], they are also valuable resources for human consumption and popular in sport fishing, and so they are, at least potentially, useful organisms for monitoring purposes.

The possibility of using fish for MPs biomonitoring is, however, still under discussion. For instance, preliminary investigations for the marine environments have been undertaken for Konosirus punctatus and Mugil cephalus [28], Boops boops [29,30], or other species living in the Mediterranean Sea [31]. However, deeper studies should be done in order to choose the most representative species for MPs monitoring, as suggested by a recent publication that tried to design, from the available reports in the literature, an index to identify the best species for every environment [32]. In addition, specific studies testing the suitability of cosmopolitan species as bioindicator organisms for MPs pollution are scarce, especially in freshwater environments where only one attempt has been carried out [33]. The choice of the most suitable species should consider different species characteristics and among these, its wide distribution is one of the most prominent because it allows comparisons between different locations/areas and the setting of large-scale monitoring networks [34]. Since fish life-history traits vary among and within species as well as among environmental conditions, the selection of indicator fish species and specimen characteristics (i.e., size/age, period of sampling) for biomonitoring purposes is a critical issue, especially because the specific mechanisms behind MPs ingestion are still overlooked.

Another major research gap within the MPs pollution investigations is the discrepancy between the characteristics of MPs utilized during toxicity essays and those found in the environment. Although freshwater fish are the organisms mostly utilized in laboratory experiments [35] probably because of their ease of breading, many aspects of the in-vitro studies done so far, in terms of environmental relevance, are questionable [36]. Discrepancies between laboratory and environmental conditions are, for example, (i) concentrations frequently used in in-vitro assays are frequently much higher than those found in the environment, and this could lead to experimental artifacts [37]; (ii) the involvement of very few other co-occurrent pollutants, when the complexity of the pollution status of the aquatic environments suggest that more complex contaminant matrix should be included in toxicological studies [38]; (iii) the investigation of short term exposure effect, compared to the lifetime of the hazard in nature [39]; (iv) the utilization of microbiologically clean MPs, when the possible danger represented by the biofilm presence and its composition has now been well described $[40,41]$. Since toxicological investigations that tried to counteract some of these aspects into account are still few [39,42,43], it is important to consider the possible harmful effects related to microplastics that can be highlighted by studies on wild catches.

In the past years, reviews have been published about MPs pollution in fish, mainly referring to marine species [44,45], or discussed together with other environmental compartments in well defined geographical areas, like the Meditteranean sea [46], the Indian coasts [47], or the Yellow sea in China [48]. Others are related to the possible health risk for humans due to the consumption of fish and seafood [49-51]. Finally, many tried to summarize the results obtained from laboratory trials [35,52-54]. Review about microplastic ingestion by freshwater fish exist, but are now quite old [55] or failed to summarize MPs presence in other organs and the effects on fish health [56], although giving a detailed summary of the methods for MPs extraction and characterization (for this reason not reviewed herein).

To outline the general framework of the current knowledge on this topic, evaluate the possible factors that could make fish a good proxy for MPs pollution, and assess whether it is possible to underline toxicological effects in free-living specimens, this review aims at: 
(i) summarize the data published in the scientific literature relating to MPs ingestion, entanglement in the gills, and translocation to other organs, in wild freshwater;

(ii) outline potential factors that can trigger MPs ingestion;

(iii) describe the effects on health status that have been reported examining freshwater fish wild catches.

\section{Methods}

A search within the published literature was conducted in the Web of Knowledge database using the term "microplastic* AND fish" ${ }^{*}$ on the title, abstract, and keywords on 10 May 2021. An explanatory flow chart of the decisional process used to include/exclude articles adopted in the present review is reported in Figure S1 (Supplementary Materials). The retrieved literature (a total of 1552 articles) was examined individually: only original research articles presenting new data about MPs pollution in fish, published in scientific journals and English language were firstly considered (442 articles). Among these, a subsequent subdivision was done between marine (257) and freshwater (185) species and laboratory (61 and 110 respectively) or field studies (195 and 75 respectively). Articles studying only marine species and those performing laboratory trials were considered only for bibliometric statistics (chapter 3). Articles focused on estuarine environments were considered in the present review if also freshwater species were considered, and only results about freshwater species were, when possible, extrapolated and reported here. For the assessment of the living preferences of species, the database FishBase (www.fishbase.se, accessed between 10 and 31 of May 2021) has been used. Moreover, while reading the literature retrieved, references reported were also controlled and eventually included (5 articles). Ultimately, 79 papers were considered for the writing of this review. Only for the purpose of discussion, some marine fish articles have been commented, but are not the subject of the statistics presented and results are not listed in the tables and figures here presented.

\section{Freshwater Fish Species in the Literature}

Although the microplastic pollution problem emerged in the 1970s, evidence of MPs ingestion by fish appeared only in 2010 as a result of the analysis of the stomach content of several marine fish species from North Pacific Central Gyre [57]. The first evidence of the ingestion in freshwater environments, instead, appeared only from 2013, when the possible toxicological effect exerted by either virgin or chemical-adsorbed MPs was first pointed out on the model organism Oryzias latipes [58] and when Sanchez and colleagues analyzed the contamination levels of the wild gudgeon (Gobio gobio) in French rivers [59].

Since then, 443 original research articles reporting MPs ingestion by fish were published, with a majority (62\%) focused on marine species and only a minority $(38 \%)$ specifically focused on freshwater species (Figure 1). Although this research field has received growing attention and a solid body of evidence have been built in the past decade, the level of MPs ingestion by freshwater fishes is still poorly investigated if compared with marine species: only $14 \%$ of the total number of publication are related to freshwaters, in respect to the $48 \%$ that studied marine species. The literature reports about MPs ingestion in 257 different species, with studies from over 32 different countries (Figure 2). The most studied species was the common carp Cyprinus carpio, which has been included in 12 different publications in rivers, lakes, and estuarine environments from 6 different countries, while the species that has been studied over a wider territory is the Nile tilapia (Oreochromis niloticus) that have been considered in eight different countries (Table S1 in Supplementary Materials). Studies were conducted in a vast geographic area, covering all the continents: Asia (25 publications), South America (18 publications), Europe (16 publications), North America (10 publications), Africa (7 publications), and Oceania (2 publications). The nation with the highest number of publications was China (15), followed by Brazil (13), and United States (8). In China and Brazil, the nations in which the research effort has been deeper, plastic ingestion has been investigated in 68 and 
67 different species, respectively, whereas in the other countries, the numbers were lower (Figure 2B and Table S1 Supplementary Materials).

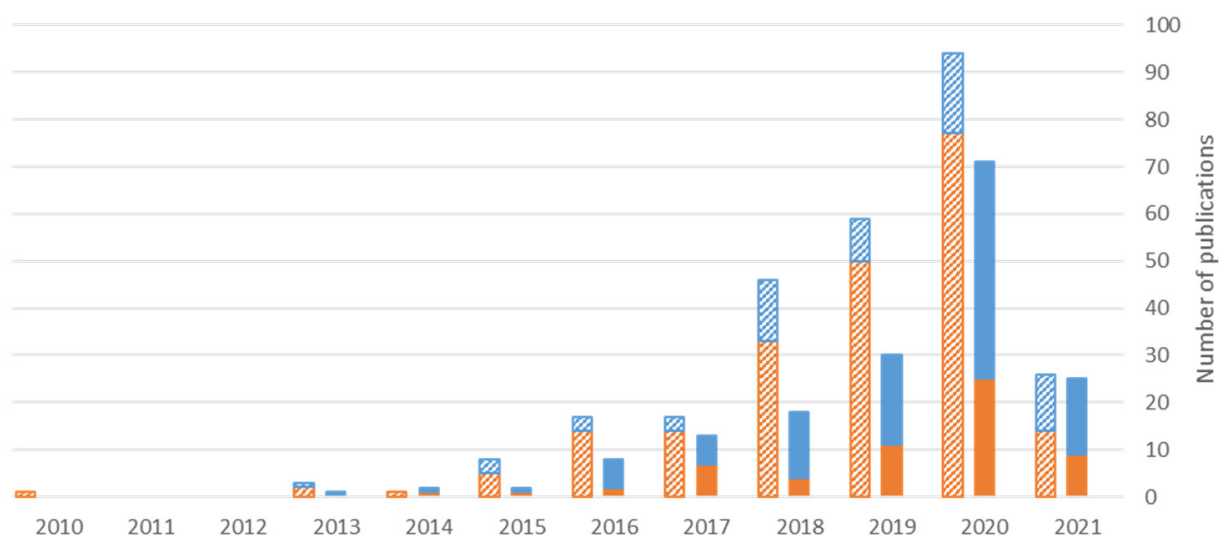

Figure 1. The number of original research articles published on freshwater (full-color) and marine (striped) species in laboratory (blue) and field (orange) studies.
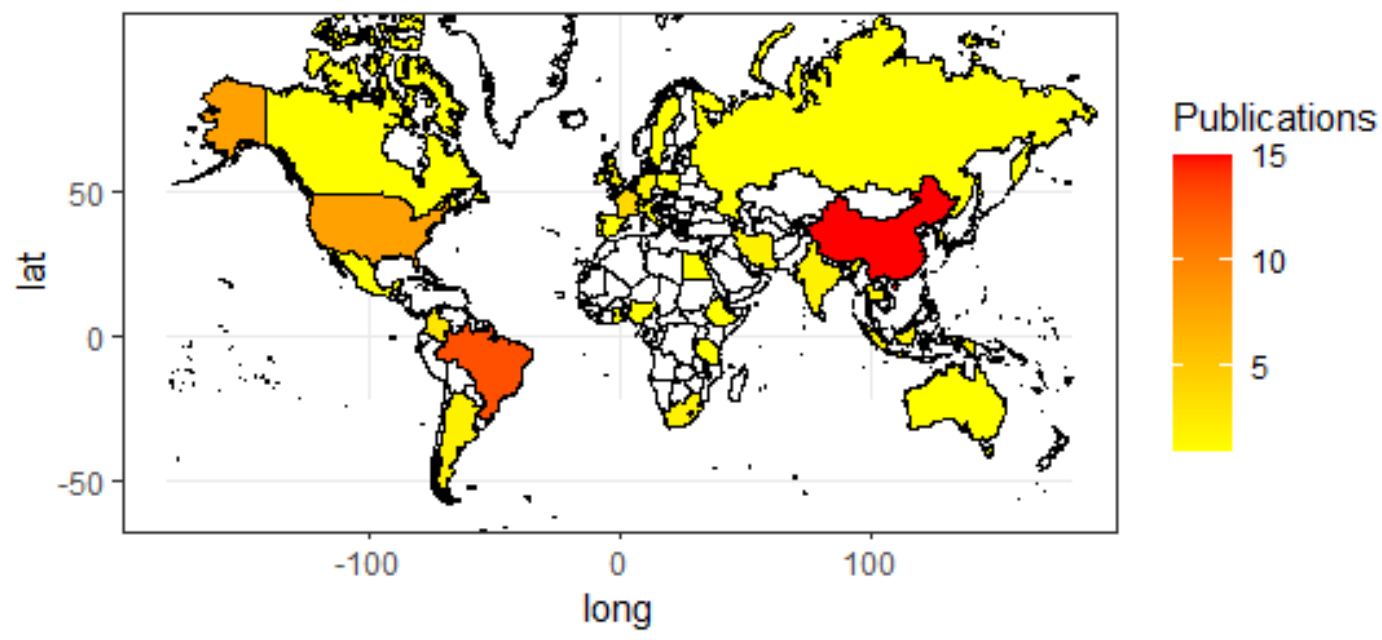

(A)

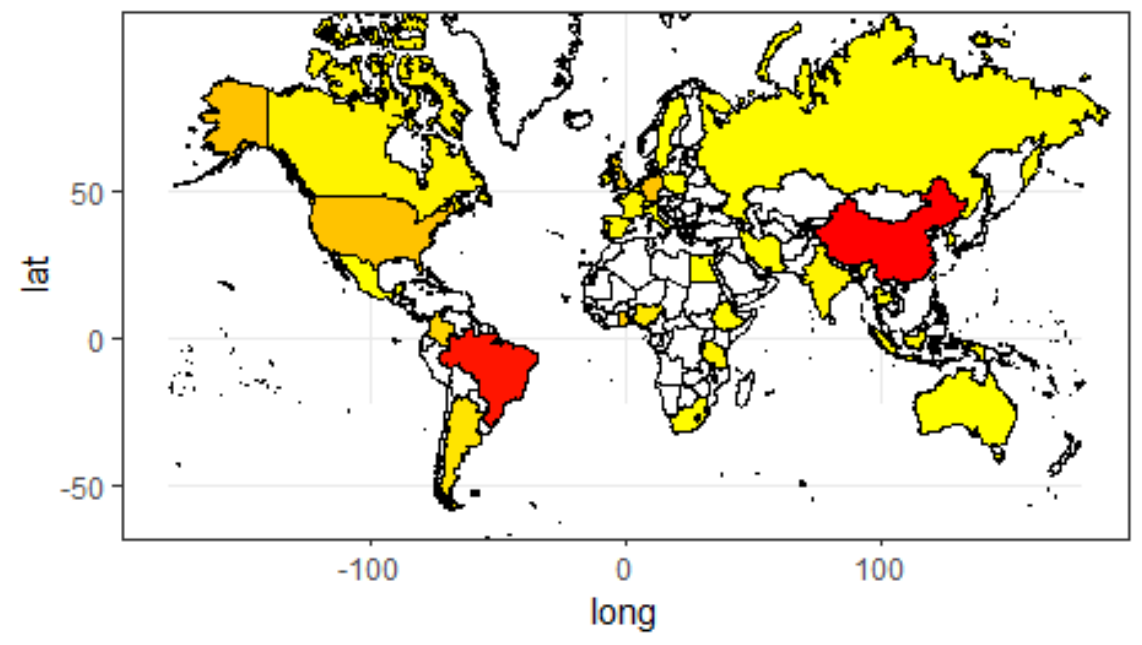

Species

(B)

Figure 2. Cont. 


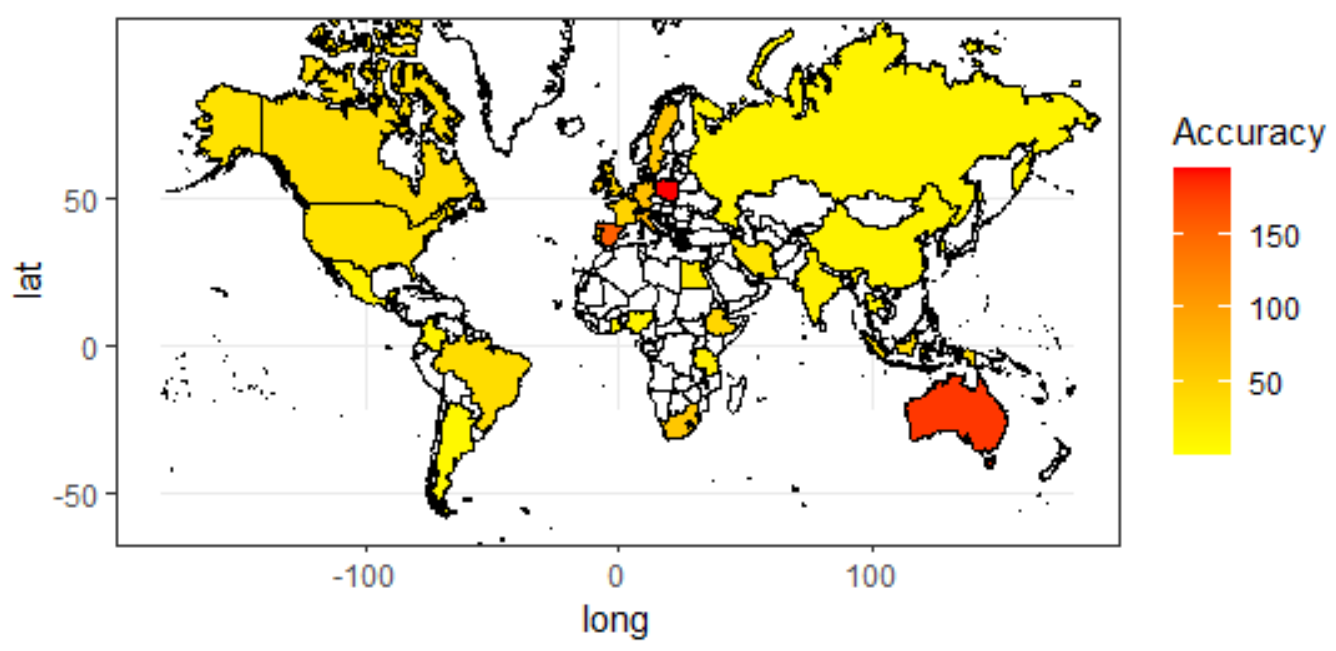

(C)

Figure 2. World map with the number of publications about MPs ingestion in freshwater fish (A), the number of species (B), and the number of specimens analyzed each species (C).

Together with the assessment of ingestion by wild fish populations, a remarkable amount of publications (39\%) reported about laboratory studies in which fish were reared with an MPs supplemented diet to unveil MPs toxicity mechanisms. Within this field, freshwater species have had great attention, probably because of their easier breeding condition. A total of 28 different species have been used to assess MPs toxicity in 111 different publications. The most frequently utilized model organism is zebrafish Danio rerio (36\% of the publications), followed by Japanese rice fish Oryzias latipes (10\%) and rainbow trout Oncorhynchus mykiss (8\%).

\section{MPs Ingestion}

The accumulation of MPs in the freshwater fish digestion tracts of field-based studies has been assessed. All of the 79 works retrieved from the literature search reported about MPs presence in the gastrointestinal tract. In fact, research about microplastic ingestion in wild catches is mainly based on the gastrointestinal tract, which is considered an external route in continuity with the environment from the mouth to the anus of fishes [60]. Among the 79 articles published, several (32, $40 \%$ of the total) do not perform any kind of chemical analysis on the particles isolated [12,59,61-90]. Visual observation can be misleading, and more importantly, the calculated value of MPs presence could be either an under or an overestimation of the actual number of MPs and, therefore, it is not comparable. For these reasons, general results from the articles that missed a chemical control have been discussed in this review, but their values of MPs contamination are not summarized in Table 1.

Freshwater bodies investigated were mainly rivers ( 35 publications), but studies on lakes (14 publications), estuarine environments (18 publications), aquaculture ponds (5 publications), wetlands or mangrove forests (4 publications), and drinking water reservoirs (4 publications) were also conducted (Table 1). In twenty-five studies MPs were found in more than $50 \%$ of the individuals investigated, and in twelve of these, have been found environments or species in which MPs were present in more than $90 \%$ of the specimens (e.g., [91-96]). Just in ten works were MPs observed in a percentage equal to or lower than $20 \%$ (Table 1, e.g., [97-103]). MPs abundance ranged from values of 0-4 particles per individual [104-108] to maximum observations of $~ 6-30$ items per fish [92,93,109-111]. The overall MPs morphologies more frequently observed were fibers that have been identified in more than $80 \%$ of studies. Chemical characterization of particles occurred in $57 \%$ of works analyzed and polymers like PE, PS, PP, rayon, nylon, PES, cellophane, acrylonitrile, and fibers of natural origin [109] were often identified. 


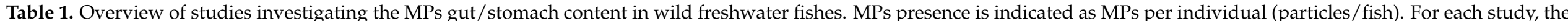

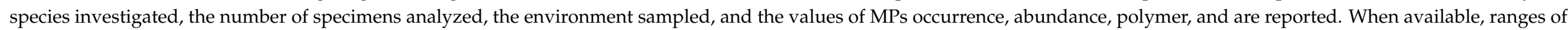

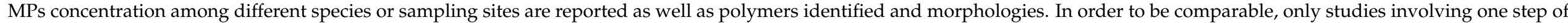
chemical confirmation of the synthetic nature of the particles counted are listed.

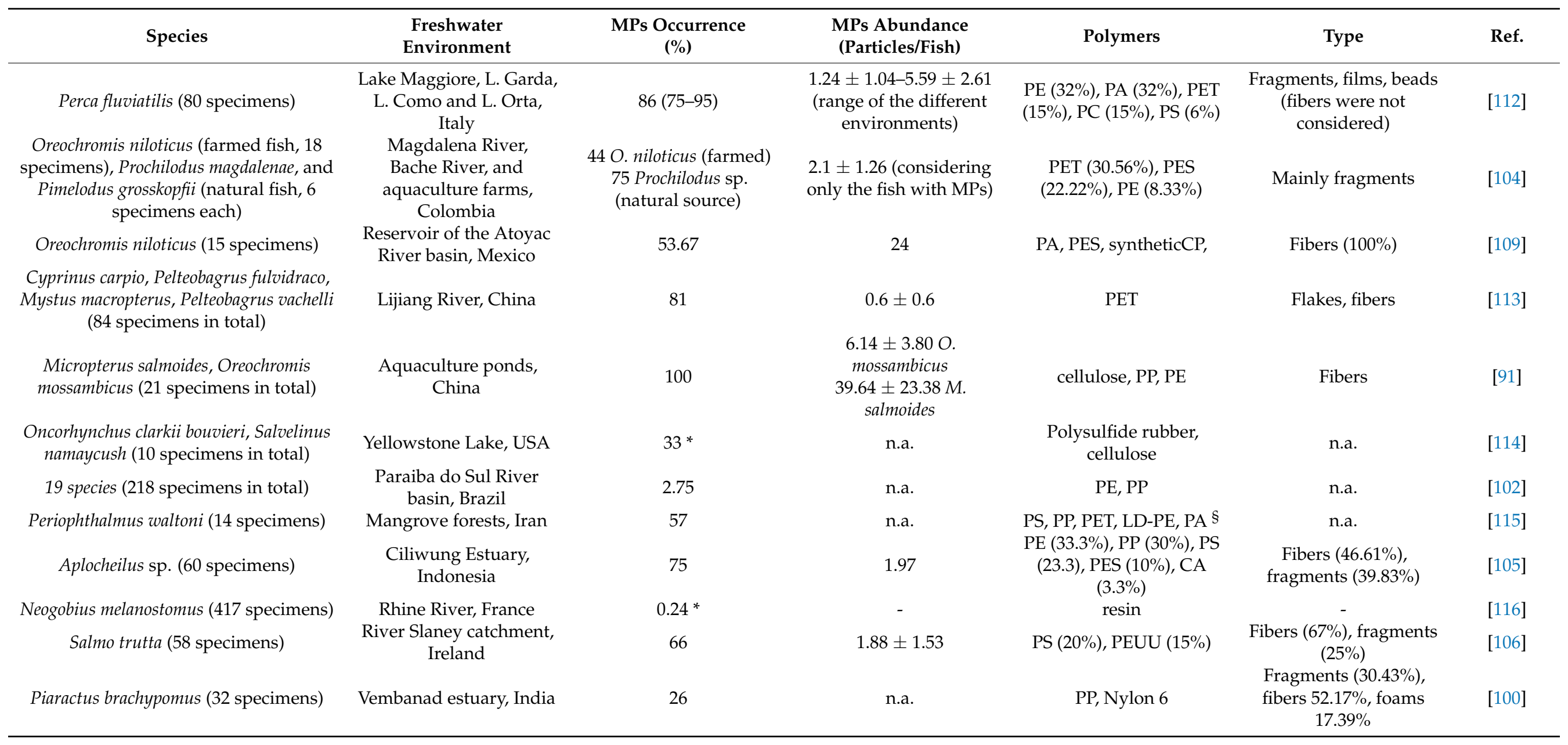


Table 1. Cont

\begin{tabular}{|c|c|c|c|c|c|c|}
\hline Species & $\begin{array}{c}\text { Freshwater } \\
\text { Environment }\end{array}$ & $\begin{array}{c}\text { MPs Occurrence } \\
(\%)\end{array}$ & $\begin{array}{l}\text { MPs Abundance } \\
\text { (Particles/Fish) }\end{array}$ & Polymers & Type & Ref. \\
\hline $\begin{array}{c}\text { Clarias gariepinus, Cyprinus carpio, } \\
\text { Carassius carassius, Oreochromis niloticus } \\
\text { (180 specimens in total) }\end{array}$ & Lake Ziway, Ethiopia & 35 & $\begin{array}{l}4 \text { (median) } \\
\text { (range 1-26) }\end{array}$ & PP, PE and alkyd-varnish & n.a. & [117] \\
\hline Monopterus albus (48 specimens) & $\begin{array}{l}\text { Aquaculture ponds, } \\
\text { China }\end{array}$ & n.a. & $2.4 \pm 0.8$ & PE (91\%), PP (7.8\%) & Films, fibers & [118] \\
\hline $\begin{array}{l}\text { Cyprinus carpio, Carassius auratus, } \\
\text { Pseudogobio esocinus, Micropterus } \\
\text { salmoides, and Zacco platypus (14 } \\
\text { specimens in total) }\end{array}$ & $\begin{array}{l}\text { Han River (in the vicinity } \\
\text { of a WWTP), Korea }\end{array}$ & 93 & $\begin{array}{c}9.9 \pm 13.4(7.3 \pm 7.3 \\
\text { upstream and } 12.4 \pm \\
17.9 \text { downstream the } \\
\text { WWTP })\end{array}$ & PE (49\%), PP (18\%) & Fragments (97\%) & [93] \\
\hline $\begin{array}{l}\text { Oreochromis niloticus, Bagrus bayad (43 } \\
\text { specimens in total) }\end{array}$ & Nile River, Egypt & $\begin{array}{l}75.9 \text { O. niloticus } \\
78.6 \text { B. bayad }\end{array}$ & $\begin{array}{l}7.5 \pm 4.9 \text { O. niloticus } \\
4.7 \pm 1.7 \text { B. bayad }\end{array}$ & PE, PET, PP & $\begin{array}{l}\text { Fibers }(65 \%) \text {, films } \\
(26.5 \%) \text {, fragments } \\
(8.5 \%)\end{array}$ & [119] \\
\hline $\begin{array}{c}\text { Hemiculter leucisculus, } \\
\text { Hypophthalmichthys molitrix, Carassius } \\
\text { auratus, Cyprinus carpio (126 specimens } \\
\text { in total) }\end{array}$ & $\begin{array}{l}\text { Rivers } 30 \mathrm{~km} \text { north of } \\
\text { Yuyao, China Plastic City }\end{array}$ & n.a. & $1.9-6.1$ & PL, PP & $\begin{array}{c}\text { Fibers }(86 \%) \text {, fragments } \\
(14 \%)\end{array}$ & [120] \\
\hline $\begin{array}{c}\text { Leiognathus equulus, Pomadasys argenteus, } \\
\text { Oreochromis niloticus ( } 27 \text { specimens in } \\
\text { total) }\end{array}$ & Fengshan River, Taiwan & n.a. & $14-94$ & PP, PA, PE & $\begin{array}{l}\text { Fibers }(\sim 50 \%) \text {, fragments } \\
\qquad(\sim 50 \%)\end{array}$ & [110] \\
\hline $\begin{array}{l}\text { Cyrinus carpio, Carassius cuvieri, Lepomis } \\
\text { macrochirus, Micropterus salmoides, } \\
\text { Silurus asotus, Channa argus (6 } \\
\text { specimens in total) }\end{array}$ & Han River, Korea & 100 & $22.0 \pm 16.0$ & PFTE, PE and rayon & $\begin{array}{l}\text { Fragments }(>94 \%) \text {, fibers } \\
\qquad(\sim 6 \%)\end{array}$ & [92] \\
\hline $\begin{array}{c}\text { Chanos chanos ( } 3 \text { specimens in each } \\
\text { location, } 18 \text { in total) }\end{array}$ & $\begin{array}{l}\text { Aquaculture pons, } \\
\text { Indonesia }\end{array}$ & n.a. & $\begin{array}{c}2.666 \pm 2.233-1.333 \pm \\
0.577 \text { (range of the } \\
\text { different ponds, both gut } \\
\text { and gills were } \\
\text { considered together) }\end{array}$ & PP and PE & Fragments & [121] \\
\hline $\begin{array}{l}\text { Leiognathus sp., Ambassis ambassis, } \\
\text { Clarias batrachus ( } 38 \text { specimens in total) }\end{array}$ & Cochin estuary, India & 21 & n.a. & nylon, $\mathrm{CP}, \mathrm{PE}$ blends $\S$ & n.a. & [122] \\
\hline
\end{tabular}


Table 1. Cont.

\begin{tabular}{|c|c|c|c|c|c|c|}
\hline Species & $\begin{array}{c}\text { Freshwater } \\
\text { Environment }\end{array}$ & $\begin{array}{c}\text { MPs Occurrence } \\
(\%)\end{array}$ & $\begin{array}{l}\text { MPs Abundance } \\
\text { (Particles/Fish) }\end{array}$ & Polymers & Type & Ref. \\
\hline $\begin{array}{l}\text { Cynoglossus trigrammus, Glossogobius } \\
\text { giuris, Boleophthalmus pectinirostris, } \\
\text { Acanthogobius flavimanus, Muraenesox } \\
\text { cinereus, Bostrychus sinensis, Taenioides } \\
\text { anguillaris, Mugil cephalus, Polydactylus } \\
\text { sexfilis, Coilia mystus, Leiognathus } \\
\text { ruconius (152 specimens in total) }\end{array}$ & $\begin{array}{c}\text { Pearl River Estuary, } \\
\text { China }\end{array}$ & n.a. & $\begin{array}{l}0.2-0.88 \text { (range of the } \\
\text { different species) }\end{array}$ & $\begin{array}{c}\text { PET }(38.2 \%), \text { PP-PE } \\
\text { copolymer }(27.3 \%), \text { CP } \\
(25.5 \%), \text { poly } \\
\text { (acrylonitrile) }(3.6 \%), \text { PP } \\
(1.8 \%), \text { PE }(1.8 \%)^{\S}\end{array}$ & $\begin{array}{c}\text { Fibers }(93.45 \%) \\
\text { fragments }(5.95 \%), \text { films } \\
(0.60 \%)^{\S}\end{array}$ & [108] \\
\hline 14 species ( 154 specimens in total) & $\begin{array}{l}\text { Pozas Ustria and Navío } \\
\text { mangrove ecosystems, } \\
\text { Colombia }\end{array}$ & 7 & n.a. & Nylon, EVA, latex & $\begin{array}{l}\text { Filaments }(55 \%) \\
\text { Fragments }(23 \%) \\
\text { Films }(19 \%) \\
\text { Foams }(3 \%) \S\end{array}$ & {$[123]$} \\
\hline 14 species (45 specimens in total) & $\begin{array}{l}\text { Zhanjiang mangrove } \\
\text { wetland, China }\end{array}$ & 100 & $\begin{array}{l}0.6-6.5 \text { (range of the } \\
\text { different species) }\end{array}$ & $\begin{array}{c}\text { PE (35\%), PET, PP, PS, } \\
\text { PU, PA CP }\end{array}$ & $\begin{array}{c}\text { Fibers }(70 \%), \\
\text { Fragments }(18 \%) \text { Film } \\
(9 \%) \\
\text { Pellet }(3 \%) \S\end{array}$ & {$[124]$} \\
\hline $\begin{array}{c}\text { Ambassis dussumieri, Oreochromis } \\
\text { mossambicus, Terapon jarbua (174 } \\
\text { specimens in total) }\end{array}$ & $\begin{array}{l}\text { St. Lucia, Umgeni, } \\
\text { Durban Harbour and } \\
\text { Isipingo esturaines, } \\
\text { South Africa }\end{array}$ & $52 \S$ & $0.787 \pm 1.00 \S$ & $\begin{array}{c}\text { rayon }(70.4 \%), \text { PE } \\
(10.4 \%), \text { nylon }(5.2 \%) \\
\text { PVC }(3.0 \%)^{\S}\end{array}$ & $\begin{array}{c}\text { Fibers }(68 \%) \\
\text { Fragments }(21 \%) \S\end{array}$ & [107] \\
\hline Gambusia holbrooki (180 specimens) & $\begin{array}{l}\text { Greater Melburne Area } \\
\text { Rivers, Australia }\end{array}$ & $3.3-38.3$ & $0.18 \pm 0.84-1.13 \pm 1.57$ & PL, Rayon & Mainly fibers & [33] \\
\hline $\begin{array}{l}\text { Monopterus albus, Misgurnus } \\
\text { anguillicaudatus (66 specimens in total) }\end{array}$ & $\begin{array}{l}\text { Agricultural ponds } \\
\text { (Rice-fish co-culture } \\
\text { plants), China }\end{array}$ & n.a. & $0.0 \pm 0.0-4.7 \pm 0.9$ & PE, PP & Mainly fibers & {$[125]$} \\
\hline Prochilodus lineatus (21 specimens) & Paraná River, Argentina & 100 & 9.9 & n.a. & Mainly fibers & [94] \\
\hline Gobio gobio (78 specimens) & Flemish River, Belgium & 9 & n.a. & $\begin{array}{c}\text { EVA, PP, PET, PVC, PVA, } \\
\text { PA }\end{array}$ & Fibers, foams, films & {$[103]$} \\
\hline $\begin{array}{c}\text { Serrasalmidae, } 16 \text { species (172 specimens } \\
\text { in total) } \\
\text { Hypophthalmichthys molitrix, }\end{array}$ & Xingu River, Brazil & 26.7 & n.a. & $\begin{array}{l}\text { PE, PVC, PA, PP, PMM, } \\
\text { RY, PET }\end{array}$ & $\begin{array}{l}\text { Filaments }(53.1 \%), \\
\text { fragments }(46.9 \%)\end{array}$ & [97] \\
\hline $\begin{array}{l}\text { Ctenopharyngodon idella, Megalobrama } \\
\text { hoffmanni, Squaliobarbus curriculus, } \\
\text { Cirrhinus molitorella, Cyprinus carpio, } \\
\text { Carassius gibelio, Coptodon zillii, Channa } \\
\text { maculata (279 specimens in total) }\end{array}$ & $\begin{array}{c}\text { Pearl River Catchment, } \\
\text { China }\end{array}$ & 15.8 to 75.0 & $7.0 \pm 23.8$ & $\begin{array}{c}\text { PET }(37.2 \%), \text { PE }(23.1 \%), \\
\text { ethylene-propylene } \\
\text { copolymer }(21.7 \%), \text { PP } \\
(10.5 \%)\end{array}$ & $\begin{array}{c}\text { Fibers }(49.2 \%), \\
\text { fragments }(37.5 \%), \text { films } \\
(11.2 \%), \text { spheres }(2.1 \%)\end{array}$ & {$[126]$} \\
\hline
\end{tabular}


Table 1. Cont.

\begin{tabular}{|c|c|c|c|c|c|c|}
\hline Species & $\begin{array}{l}\text { Freshwater } \\
\text { Environment }\end{array}$ & $\begin{array}{l}\text { MPs Occurrence } \\
(\%)\end{array}$ & $\begin{array}{l}\text { MPs Abundance } \\
\text { (Particles/Fish) }\end{array}$ & Polymers & Type & Ref. \\
\hline Carassius auratus (11 specimens) & Poyang Lake, China & 90.9 & $9.37 \pm 5.37$ & PP, PE, nylon, PVC & Fibers, fragments, films & [95] \\
\hline $\begin{array}{l}\text { Salvelinus fontinalis, Oncorhynchus } \\
\text { mykiss, Micropterus dolomieu (10 } \\
\text { specimens each) }\end{array}$ & $\begin{array}{l}\text { Huron, Ontario and Eire } \\
\text { lakes, USA }\end{array}$ & $\begin{array}{l}30 \text { S. fontinalis } \\
40 \text { O. mykiss } \\
50 \text { M. dolomieu }\end{array}$ & $\begin{array}{c}0.40 \pm 0.70-0.70 \pm 0.82 \\
\text { (range of the different } \\
\text { species) }\end{array}$ & PE, SAN, PS, nylon, PET & $\begin{array}{l}\text { PET fibers }(44 \%), \text { PE } \\
\text { fragments }(19 \%), \text { Nylon } \\
\text { fibers }(19 \%), \text { SAN }(13 \%), \\
\text { PS fragments }(6 \%)\end{array}$ & [127] \\
\hline $\begin{array}{l}\text { Caquetaia kraussii, Eugerres plumieri (75 } \\
\text { specimens in total) }\end{array}$ & $\begin{array}{l}\text { Ciénaga Grande de } \\
\text { Santa Marta, estuary, } \\
\text { Colombia }\end{array}$ & $\begin{array}{l}\text { 8.6 C. kraussii } \\
5.0 \text { E. plumieri }\end{array}$ & n.a. & PS, PP & $\begin{array}{c}\text { Fibers }(89.5 \%), \\
\text { fragments }(10.5 \%)\end{array}$ & [128] \\
\hline $\begin{array}{l}\text { Lateolabrax maculatus, Coilia nasus, Coilia } \\
\text { mystus, Hemibarbus maculatus, } \\
\text { Synechogobius ommaturus (Acanthogobius } \\
\text { ommaturus), Planiliza haematocheilus } \\
\text { (Liza haematocheila), Boleophthalmus } \\
\text { pectinirostris ( } 97 \text { specimen in total) }\end{array}$ & $\begin{array}{l}\text { Hangzhou Bay and } \\
\text { Yangtze estuary, China }\end{array}$ & $\begin{array}{l}22-100 \% \text { (range of } \\
\text { different species and } \\
\text { sampling point) }\end{array}$ & $\begin{array}{l}0.3 \pm 0.5-5.3 \pm 2.4 \\
\text { (range of the different } \\
\text { species and sampling } \\
\text { point) }\end{array}$ & PE, PP, PET & n.a. & [129] \\
\hline $\begin{array}{l}\text { Dorosoma cepedianum, Catostomus } \\
\text { commersonii, Pimephales promelas, } \\
\text { Carpoides cyprinus, Notropis stramineus, } \\
\text { Notropis hudsonius, Fundulus diaphanous, } \\
\text { Micropterus sp., Notropis atherinoides, } \\
\text { Neogobius melanostomus, Cyprinella } \\
\text { spiloptera (74 specimens in total) }\end{array}$ & $\begin{array}{l}\text { Lake Michigan } \\
\text { tributaries, USA }\end{array}$ & 85 & $10 \pm 2.3-13 \pm 1.6$ & n.a. & Mainly fibers & [111] \\
\hline Gymnocypris przewalskii (10 specimens) & Qinghai Lake, China & 100 & $5.4 \pm 3.6(2-15)$ & PE, PS, nylon, and PP. & Fibers, films & [130] \\
\hline Rutilus rutilus (64 specimens) & Thames River, UK & 33 & $0.69 \pm 1.25$ & PP, PE, PL & $\begin{array}{l}\text { Fibers }(75 \%) \text {, fragments } \\
(22.7 \%), \text { films }(2.3 \%)\end{array}$ & [131] \\
\hline Squalius cephalus (60 specimens) & $\begin{array}{l}\text { Seine and Marne River, } \\
\text { France }\end{array}$ & 15 & n.a. & PET, PP, PEVA & Fibers $(83 \%)$ & [99] \\
\hline $\begin{array}{l}\text { Dicentrarchus labrax, Platichthys flesus } \\
\text { (40 specimens each species) }\end{array}$ & $\begin{array}{l}\text { Mondego estuary, } \\
\text { Portugal }\end{array}$ & $\begin{array}{l}23 \text { D. labrax } \\
13 \text { P. flesus }\end{array}$ & $\begin{array}{l}0.30 \pm 0.61 \text { D. labrax } \\
0.18 \pm 0.55 \text { P. flesus }\end{array}$ & $\begin{array}{l}\text { PE }(31 \%), \text { PP }(14 \%), \\
\text { polyacrylonitrile }(14 \%), \\
\text { PE }(6 \%), \text { nylon }(5 \%), \\
\text { rayon }(30 \%)\end{array}$ & $\begin{array}{c}\text { Fibers }(96 \%), \text { fragments } \\
\qquad(4 \%)\end{array}$ & [132] \\
\hline Colomesus psittacus (2 specimens) & $\begin{array}{c}\text { Amazon River estuarine, } \\
\text { Brazil }\end{array}$ & 0 & 0 & - & - & [133] \\
\hline
\end{tabular}


Table 1. Cont.

\begin{tabular}{|c|c|c|c|c|c|c|}
\hline Species & $\begin{array}{l}\text { Freshwater } \\
\text { Environment }\end{array}$ & $\begin{array}{c}\text { MPs Occurrence } \\
(\%)\end{array}$ & $\begin{array}{l}\text { MPs Abundance } \\
\text { (Particles/Fish) }\end{array}$ & Polymers & Type & Ref. \\
\hline $\begin{array}{c}\text { Cyprinus carpio, Carassius auratus, } \\
\text { Hypophthalmichthys molitrix, } \\
\text { Pseudorasbora parva, Megalobrama } \\
\text { amblycephala, Hemiculter bleekeri (18 } \\
\text { specimens each) }\end{array}$ & Taihu lake, China & 95.70 & $1.8 \pm 1.7-3.8 \pm 2.0$ & CP, PET, PL & $\begin{array}{c}\text { Fibers }(90.3-100 \%) \\
\text { fragments }(15 \%), \text { films } \\
(1.1-5.9 \%)\end{array}$ & [96] \\
\hline Salmo trutta (62 specimens) & Coastal water, Sweden & 68 & n.a. & $\begin{array}{l}\text { PE, alkyd resin, PS, } \\
\text { polymethyl methacrylate }\end{array}$ & n.a. & [134] \\
\hline $\begin{array}{c}\text { Culter alburnus, Culter dabryi, Culter } \\
\text { mongolicus, Culter oxycephaloides, } \\
\text { Cyprinus carpio, Pelteobagrus nitidus, } \\
\text { Pelteobagrus fulvidraco, Pelteobaggrus } \\
\text { vachelli, Pseudobagrus ussuriensis, } \\
\text { Siniperca chuatsi, Sinibrama wui, } \\
\text { Squalidus argentatus (35 specimens in } \\
\text { total) }\end{array}$ & Xiangxi River, China & 25.7 & $0-1.5 \pm 1.38$ & PE, nylon & Lines, Sheets & [135] \\
\hline $\begin{array}{c}\text { Platichthys flesus, Osmerus eperlanus (76 } \\
\text { specimens in total) }\end{array}$ & Thames River, UK & $20-90 \%$ & $0.2 \pm 0.42-0.85 \pm 1.17$ & PA, nylon, PE, PET & Fibers $(100 \%)$ & [136] \\
\hline $\begin{array}{l}\text { Lates niloticus, Oreochromis niloticus (20 } \\
\text { specimens each) }\end{array}$ & Lake Vittoria, Tanzania & $20 \%$ & n.a. & $\begin{array}{l}\text { PE, polyurethane, PES, } \\
\text { PE/PP copolymer, } \\
\text { silicone rubber }\end{array}$ & n.a. & [98] \\
\hline $\begin{array}{l}\text { Alburnus alburnus, Rutilus rutilus, Perca } \\
\text { fluviatilis, Leuciscus leuciscus (10 } \\
\text { specimens each) }\end{array}$ & $\begin{array}{l}\text { Lake Geneva, } \\
\text { Switzerland }\end{array}$ & $7.5 \%$ & n.a. & n.a. & Fibers, fragments & [101] \\
\hline
\end{tabular}

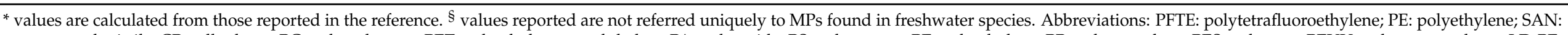

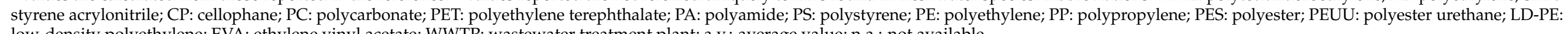
low-density polyethylene; EVA: ethylene vinyl acetate; WWTP: wastewater treatment plant; a.v.: average value; n.a.: not available 


\section{MPs Trapped in the Gills}

Although MPs in wild freshwater fishes were observed mainly in the gastrointestinal tract due to assumption through feeding, recently, there is always more evidence of MPs found in the gills of riverine fishes through a probably passive uptake $[60,96,137]$. Hurt and colleagues [12] observed MPs in gizzard shad (Dorosoma cepedianum) and largemouth bass (Micropterus salmoides) gills collected in Bloomington and Evergreen lakes (Illinois, USA). MPs values ranged from 1 to 30 particles per fish, and concentrations found in gizzard shad were significantly higher in the gills than in the gut. Two freshwater fish species (Oreochromis niloticus and Cirrhinus molitorella) were collected in the north and west rivers of Guangdong province (China) by [85], and the MPs presence were thoroughly investigated in the gut and gills of animals. The concentration of MPs in O. niloticus guts $(0.239$ items $/ \mathrm{g})$ was greater than found in C. molitorella gills $(0.056 \mathrm{items} / \mathrm{g})$, while opposite results revealed a more significant value of MPs in C. molitorella gills than in gut (gut: 0.373 items/g, gill: 0.768 items/g). Other authors [92] found MPs in the gills of six different genera of freshwater fishes (common carp Cyrinus carpio, Japanese white crucian carp Carassius cuvieri, bluegill Lepomis macrochirus, largemouth bass Micropterus salmoides, amur catfish Silurus asotus, and northern snakehead Channa argus) inhabiting the Han river in South Korea. They observed from 1 to 16 particles per fish (mean: $8.3 \pm 6.0$ ) in the gills compared to 4-48 particles/fish (mean: $22.0 \pm 16.0$ particles/fish) revealed in the intestine of the same fishes. Farmed and wild fish (Oreochromis niloticus, the former and Prochilodus magdalenae, and P. grosskopfii the latter) from the same region in Colombia were investigated for their MPs contamination, but no statistical differences were found both between the content in the gut and the gills and between the different sampling points [104]. The presence of MPs in the gills of fishes collected in estuarine areas has also been investigated. Su and colleagues [129] analyzed 14 marine and freshwater commercial species collected in Chinese estuarine areas and found MPs with comparable frequencies and amounts in the gills with respect to the gut (respectively 0.3 to 5.3 particles/fish in the gut and 0.3 to 2.6 particles/fish in the gills). Instead, MPs in the gills were significantly smaller than those found in the guts, and that fibers were more frequent [129]. On these bases, the recruitment of MPs in organs differing from those involved with feeding suggests not only an incidentally or deliberately ingestion during alimentation from the water column or sediment or an indirect assumption through contaminated prey but that other factors (feeding strategy, fish anatomy, adherence and surrounding level of MPs pollution) may be relevant for MPs accumulation and that potentially translocation in fishes can occur [138,139].

\section{MPs Translocation to Other Organs}

Some authors recently started to investigate the presence of MPs in the full body of the fish, not limiting the research to the digestive tract only. The majority of these studies have been focused mainly on marine species and laboratory experiments, and works concerning wild fishes of freshwater environments are still very few (Figure S2 in Supplementary Materials). The chub Squalius cephalus [99] was caught in the Marne and Seine rivers around Paris (France) to evaluate the presence of particles of synthetic origin in the stomach, muscle, and liver fishes. Fibers of anthropogenic origin were found predominantly in the stomach of individuals ( $25 \%$ ), and $5 \%$ of fish livers also contained one or more particles. Conversely, no plastic was found in the muscle tissue. Other three freshwater fishes (Oreochromis niloticus, Prochilodus magdalenae, and Pimelodus grosskopfii) were captured from the Magdalena River (Colombia) and MPs presence was also investigated in the muscle of individuals [104], which showed a lower amount of MPs (0.2 item/g) than gut and gills. The most relevant MPs detected in the muscle were PET, PP, and nylon fragments. The last work concerning wild freshwater catches is [33], in which the authors investigated a natural habitat (wetlands in Australia) using mosquitofish Gambusia holbrooki to monitor the presence of MPs in the body and heads of individuals caught. More MPs of bigger size (0.6 items/fish) were observed in fishes' bodies than in the heads (0.1 items/fish). MPs' 
sizes ranged from $90-4860 \mu \mathrm{m}$ in bodies and $222-2001 \mu \mathrm{m}$ in the heads. Polyester was the predominant polymer, and fibers the most recurrent shape. Another estuary environment of east China has been investigated for the distribution of MPs in different organs (gut, gills, liver, muscle) of a commercial fish (sea bass Lateolabrax maculatus) and other freshwater wild catches (see Table 1). All the anthropogenic items found in the flesh of individuals were revealed to be non-plastic items attributed to background contamination [129].

Other evidence of studies that considered the distribution of MPs in organs differing from the digestive tract were conducted prevalently in marine environments, and since there are still so few studies in this area, it is worth mentioning them here as well. Ref. [140] studied commercially important species of fishes of the Musa estuary (north part of the Persian Gulf) for the presence and translocation of MPs to other tissues (skin, muscle, gut, gills, liver). The most abundant sizes ranging from 100 and $250 \mu \mathrm{m}$ were found in S. sihama, P. indicus, and P. semisulcatus, while sizes between 250 and $500 \mu \mathrm{m}$ were observed in C. abbreviates and S. tumbil. Larger MPs were mostly observed in digestive tissues (reaching values $>1000 \mu \mathrm{m}$ ) and gills $(500-1000 \mu \mathrm{m})$ due to relatively little obstruction of the gastrointestinal tract with respect to other organs. Conversely, [49] found more MPs in the gut $(1.2 \pm 2.0$ particles/fish $)$ than in the muscle $(0.054 \pm 0.099$ items $/ g)$ of three commercial fishes (seabass Dicentrarcus labrax, Atlantic mackerel Trachurus trachurus, Atlantic chub mackerel S. colias) collected from the North-East Atlantic Ocean. Fibers and fragments were observed in all the species and tissues, while pellets morphology was found only in the digestive tract. In the dorsal muscle of all species, small fragments lower than $100 \mu \mathrm{m}$ were more abundant than bigger ones $(101-5000 \mu \mathrm{m})$. These still recent results seem to confirm the possible translocation of MPs to other organs of wild fishes, although the routes of this translocation are still not completely clear.

\section{Predicting MPs Ingestion}

In the majority of the studies that reported MPs ingestion in the wild freshwater populations, the analysis is limited to the quantification of the particles present, rather than to the investigation of possible effects on fish health status. However, although in a minority, several different aspects inherent to MPs transfer to fish were investigated. One of the more frequently investigated is the possibility that the ingestion of MPs could directly correlate with the anthropization level of the area sampled. For instance, a study from Garcia and colleagues [90] showed that fish from highly urbanized streams in Southern Brazil had a higher number of ingested particles respect those from less impacted areas. A similar result has also been found in the Brazor River watershed (Texas, USA), where the ingestion of MPs by two species of sunfish (Lepomis macrochirus and Lepomis megalotis) was correlated with the presence of major roadways in the proximity of the sampling point [73]. The same was also found for Rutilus rutilus in the River Thames, where the MP ingestion increase with distance from the source, reflecting the increase in the anthropogenic impact [131].

Although microplastic uptake by fish is likely affected by MPs abundance, this correlation seems not to be strictly dependent on MPs abundance in water or sediments. Several studies demonstrated that higher MPs environmental concentration does not necessarily translate into higher ingestion $[71,87,106,111,121]$. Other factors, in fact, can drive the ingestion of MPs, as demonstrated by laboratory experiments with zebrafish (Danio rerio) by Kim and colleagues [141], in which a higher food availability has been demonstrated to trigger an increased MPs ingestion, independently of the MPs concentration in water. Khosrovyan and colleagues [142] found that particle ingestion was not affected by MPs presence in water, but more probably affected by the sedimentation/resuspension due to the movement of the fish that keeps MPs floating in the water column, more available for the ingestion. A similar effect has also been underlined in a field study where the ingestion of small MPs (fragments smaller than $300 \mu \mathrm{m}$ ) was more correlated to suspended solid concentration than the mere presence of MPs in the water [110]. These may indicate the presence of different driving factors, more related to the feeding strategies adopted by the fish. Ingestion can occur indirectly because of ingestion during feeding or because it was already ingested by the prey, or directly because it was mistaken for prey. In the latter 
case, MPs characteristics resembling natural prey (in color, shape, or dimensions) together with the abundance of the natural preys are possible drivers determining higher ingestion $[67,112]$, like what has been described for Carassius auratus in Poyang Lake (China) that showed a preference for white MPs pellets, probably because of their similarity to plankton appearance in water [95]. On the other hand, the appearance of microplastics can also be a determining factor in non-ingestion: a detailed analysis of the stomach content parallel to MPs isolation could reveal that fish could identify and avoid ingestion of MPs particles bigger than $335 \mu \mathrm{m}$, as described in a study on MPs ingestion by the blueback herring, Alosa aestivalis, in the Hudson River (New York, USA) [68]. Similarly, the trophic guild, the characteristic directly responsible for the ingestion mechanism, has also been investigated as a proxy of MPs ingestion and omnivores [63,90,126] and zoobentivores [111] were found with higher concentrations in their stomach, although there are reports in which this correlation was missing $[97,106]$.

Length and weight have been frequently found positively correlated with MPs ingestion, with larger and heavier fish having an increased risk of ingestion $[12,33,73,93,131]$. The existence of a correlation between length and MPs ingestion could be explained by the fact that increased body dimensions drive increased feeding rates and subsequent a higher possibility to ingest the MPs present in the environment. However, there are several studies in which this correlation was absent $[106,109,112]$, or present only during the early life stages, like in the case of the gizzard shad, Dorosoma cepedianum, that lose this correlation after its ontogenic diet shift from zooplanktivory to detritivory at increasing body size [12].

\section{Effects of MPs Ingestion in Wild Catches}

The possibility to retrieve information on the detrimental effects of MPs presence directly from wild catches surveys would be a straightforward way to speed up the assessment of MPs toxicity. Laboratory experiments have underlined that MPs presence could affect fish health, behavior, and ecology from many different aspects [52]. Physical problems related to ingestion, like their possible accumulation in the gut, could end up in altered feeding behavior [143-146]. Inflammation has also been reported [147], together with changes in the metabolic profiles [148,149] and disturbance on the immune system [150].

Assessment of fish health during monitoring surveys in wild catches is overlooked. Moreover, studies that have considered this aspect in the marine environments are scarce, whereas in freshwater, there are very few. The easiest way to evaluate fish health is the calculation of fish health status by comparing the length and body mass, estimating the hepatosomatic index by weighting the liver during dissection, or by calculating the fullness index by quantifying the stomach content. For instance, Galafassi and colleagues [112] assessed MPs ingestion by Perca fluviatilis sampled in four deep south-alpine lakes in the North of Italy with a parallel evaluation of fish health status by the calculation of Fulton's body condition, the hepatosomatic index, and the fullness index [112]. Their results showed that fish health was not affected by MPs' ingestion, although they could find an effect on the feeding behavior underlined by the existence of a negative correlation between MPs ingestion and the fullness index. Similarly, Ryan and colleagues have assessed the selectivity with which Alosa aestivalis juveniles ingest MPs, and they found that the fish's condition coefficient was not correlated with MPs ingestion [68]. A deeper investigation was done by $\mathrm{Li}$ and colleagues [120] that sampled fishes in the vicinity of a plastic production industry and performed an histological examination of the Hemiculter leucisculus sampled to calculate the organ index of fish liver, evaluating each reaction pattern separately. They found both increased organ index and reactivity of the inflammation and circulatory disturbances in the most polluted area, with values close to those found in laboratory trials, where fish were exposed to much higher concentrations. This result suggest that the setting up of laboratory trials should consider set-up resembling the environmental condition both when considering the concentrations and the exposure time. 


\section{Conclusions and Research Needs}

The review of the literature presented here shows how widespread and noteworthy is the problem of MPs pollution in freshwater environments. One hundred and ninetynine species have been documented ingesting plastic from 29 countries, with more than 60 research articles specifically focused on MPs ingestion by wild freshwater fish. Together with the digestive tract, MPs have also been found in the gills of fish, probably because they are accidentally trapped there while breathing. Furthermore, there is also evidence that small MPs can translocate in different tissue of the organisms, thus potentially representing a risk for human health. Strong evidence, therefore, exists that and MPs may represent a serious risk to ecosystems, including freshwaters. Although the increasing attention given to this problem, the literature studies analyzed during the compilation of this review showed several critical issues. First of all, each investigation should include a chemical assessment of the synthetic origin of the isolated MPs. Visual observation can be highly misleading, as demonstrated in studies in which only a fraction of what was isolated was confirmed by FT-IR spectroscopy $[71,88,95,109,112]$, thus, a correction of visual countings is mandatory to get reliable results. In over one-third of the article reviewed here, the chemical analysis was missing. Secondly, since MPs pose greater dangers as they decrease in size, the dimensional limits of the adopted isolation protocols should always be determined and assessed. Visual observation and enumeration as well as manual sorting are not easy to perform on particles smaller than $100 \mu \mathrm{m}$, therefore, countings in this lower-dimensional range are easily biased by the protocol adopted. Making comparisons between results of studies made with different lower detection limit it is neither easy nor useful, especially if considering that the smaller dimensional range is usually the most abundant [33,91]. Furthermore, the assessment of fish health status by the evaluation of a simple index, such as those based on length-weight relationship of the total body or affected organs, should be researched whenever possible as a straightforward way to speed up the assessment of MPs toxicity.

Supplementary Materials: The following are available online at https: / www.mdpi.com/article/ 10.3390/w13162214/s1, Figure S1: Explanatory flow chart of the decisional process used to include/exclude articles in this revision; Table S1: Summary of all the fish species investigated for MPs ingestion with references to the research article, the type of environment and the country in which have been sampled. In the case of taxonomy ambiguity with species registered on FishBase (www.fishbase.se, accessed between 10 and 31 of May 2021), the name reported on the original article is reported in brackets; Figure S2: Summary of the studies that resported MPs presence in fish organs different from the whole gastrointestinal tract, that is the most frequently studied body compartment.

Author Contributions: Conceptualization, S.G. and P.V.; writing-original draft preparation, S.G. and C.C.; writing-review and editing, C.M., V.F.U., and P.V.; visualization, C.C., S.G., and C.M. Please turn to the CRediT taxonomy for the term explanation. Authorship must be limited to those who have contributed substantially to the work reported. All authors have read and agreed to the published version of the manuscript.

Funding: This research received no external funding.

Institutional Review Board Statement: Not applicable.

Informed Consent Statement: Not applicable.

Data Availability Statement: Not applicable.

Conflicts of Interest: The authors declare no conflict of interest.

\section{References}

1. PlasticEurope. Plastics-the Facts 2020; PlasticEurope: Brussels, Belgium, 2020; pp. 1-64. Available online: https://www.plasticseurope. org/application/files/5716/0752/4286/AF_Plastics_the_facts-WEB-2020-ING_FINAL.pdf (accessed on 24 June 2021).

2. Carpenter, E.J.; Smith, K.L. Plastics on the Sargasso sea surface. Science 1972, 175, 1240-1241. [CrossRef]

3. Carpenter, E.J.; Anderson, S.J.; Harvey, G.R.; Miklas, H.P.; Peck, B.B. Polystyrene spherules in coastal waters. Science 1972, 178, 749-750. [CrossRef] 
4. Colton, J.B.; Knapp, F.D.; Burns, B.R. Plastic particles in surface waters of the Northwestern Atlantic. Science 1974, 185, 491-497. [CrossRef] [PubMed]

5. Frias, J.P.G.L.; Nash, R. Microplastics: Finding a consensus on the definition. Mar. Pollut. Bull. 2019, 138, 145-147. [CrossRef]

6. de Sá, L.C.; Oliveira, M.; Ribeiro, F.; Rocha, T.L.; Futter, M.N. Studies of the effects of microplastics on aquatic organisms: What do we know and where should we focus our efforts in the future? Sci. Total Environ. 2018, 645, 1029-1039. [CrossRef]

7. Blettler, M.C.M.; Abrial, E.; Khan, F.R.; Sivri, N.; Espinola, L.A. Freshwater plastic pollution: Recognizing research biases and identifying knowledge gaps. Water Res. 2018, 143, 416-424. [CrossRef]

8. Can-Güven, E. Microplastics as emerging atmospheric pollutants: A review and bibliometric analysis. Air Qual. Atmos. Health 2021, 14, 203-215. [CrossRef]

9. EU Directive 2008/56/EC of the European Parliament and of the Council of 17 June 2008 establishing a framework for community action in the field of marine environmental policy (Marine Strategy Framework Directive). Off. J. Eur. Community 2008, L164, 1-40.

10. EU Directive 2000/60/EC of the European Parliament and of the Council establishing a framework for the Community action in the field of water policy. Off. J. Eur. Community 2000, L327, 1-73.

11. Campanale, C.; Stock, F.; Massarelli, C.; Kochleus, C.; Bagnuolo, G.; Reifferscheid, G.; Uricchio, V.F. Microplastics and their possible sources: The example of Ofanto river in southeast Italy. Environ. Pollut. 2020, 258, 113284. [CrossRef]

12. Hurt, R.; O'Reilly, C.M.; Perry, W.L. Microplastic prevalence in two fish species in two U.S. reservoirs. Limnol. Oceanogr. Lett. 2020, 5, 147-153. [CrossRef]

13. Büks, F.; Kaupenjohann, M. Global concentrations of microplastic in soils, a review. SOIL Discuss. 2020, 1-26. [CrossRef]

14. Campanale, C.; Dierkes, G.; Massarelli, C.; Bagnuolo, G.; Uricchio, V.F. A Relevant Screening of Organic Contaminants Present on Freshwater and Pre-Production Microplastics. Toxics 2020, 8, 100. [CrossRef]

15. Jeppesen, E.; Mehner, T.; Winfield, I.J.; Kangur, K.; Sarvala, J.; Gerdeaux, D.; Rask, M.; Malmquist, H.J.; Holmgren, K.; Volta, P.; et al. Impacts of climate warming on the long-term dynamics of key fish species in 24 European lakes. Hydrobiologia 2012, 694, 1-39. [CrossRef]

16. Poikane, S.; Ritterbusch, D.; Argillier, C.; Białokoz, W.; Blabolil, P.; Breine, J.; Jaarsma, N.G.; Krause, T.; Kubečka, J.; Lauridsen, T.L.; et al. Response of fish communities to multiple pressures: Development of a total anthropogenic pressure intensity index. Sci. Total Environ. 2017, 586, 502-511. [CrossRef]

17. Volta, P.; Tremolada, P.; Neri, M.C.; Giussani, G.; Galassi, S. Age-dependent bioaccumulation of organochlorine compounds in fish and their selective biotransformation in top predators from lake maggiore (Italy). Water Air Soil Pollut. 2009, 197, 193-209. [CrossRef]

18. Volta, P.; Oggioni, A.; Bettinetti, R.; Jeppesen, E. Assessing lake typologies and indicator fish species for Italian natural lakes using past fish richness and assemblages. Hydrobiologia 2011, 671, 227-240. [CrossRef]

19. Guzzella, L.M.; Novati, S.; Casatta, N.; Roscioli, C.; Valsecchi, L.; Binelli, A.; Parolini, M.; Solcà, N.; Bettinetti, R.; Manca, M.; et al. Spatial and temporal trends of target organic and inorganic micropollutants in Lake Maggiore and Lake Lugano (Italian-Swiss water bodies): Contamination in sediments and biota. Hydrobiologia 2018, 824, 271-290. [CrossRef]

20. Mazzoni, M.; Buffo, A.; Cappelli, F.; Pascariello, S.; Polesello, S.; Valsecchi, S.; Volta, P.; Bettinetti, R. Perfluoroalkyl acids in fish of Italian deep lakes: Environmental and human risk assessment. Sci. Total Environ. 2019, 653, 351-358. [CrossRef] [PubMed]

21. Karr, J.R. Assessment of Biotic Integrity Using Fish Communities. Fisheries 1981, 6, 21-27. [CrossRef]

22. Whittier, T.R. Development of IBI metrics for lakes in Southern New England. In Assessing the Sustainability and Biological Integrity of Water Resource Quality Using Fish Communities; Simon, T.P., Ed.; CRC Press: Boca Raton, FL, USA, 1999; pp. 563-584.

23. Argillier, C.; Caussé, S.; Gevrey, M.; Pédron, S.; De Bortoli, J.; Brucet, S.; Emmrich, M.; Jeppesen, E.; Lauridsen, T.; Mehner, T.; et al. Development of a fish-based index to assess the eutrophication status of European lakes. Hydrobiologia 2013, 704, 193-211. [CrossRef]

24. Ritterbusch, D.; Blabolil, P.; Erős, T.; Breine, J.; Mehner, T.; Olin, M.; Peirson, G.; Volta, P.; Poikane, S. European fish-based assessment reveals high diversity of systems for determining ecological status of lakes. Sci. Total Environ. 2021, 149620. [CrossRef]

25. Birk, S.; Bonne, W.; Borja, A.; Brucet, S.; Courrat, A.; Poikane, S.; Solimini, A.; Van De Bund, W.; Zampoukas, N.; Hering, D. Three hundred ways to assess Europe's surface waters: An almost complete overview of biological methods to implement the Water Framework Directive. Ecol. Indic. 2012, 18, 31-41. [CrossRef]

26. Miranda, D.A.; de Carvalho-Souza, G.F. Are we eating plastic-ingesting fish? Mar. Pollut. Bull. 2016, 103, 109-114. [CrossRef]

27. Wesch, C.; Bredimus, K.; Paulus, M.; Klein, R. Towards the suitable monitoring of ingestion of microplastics by marine biota: A review. Environ. Pollut. 2016, 218, 1200-1208. [CrossRef]

28. Zhang, C.; Wang, S.; Sun, D.; Pan, Z.; Zhou, A.; Xie, S.; Wang, J.; Zou, J. Microplastic pollution in surface water from east coastal areas of Guangdong, South China and preliminary study on microplastics biomonitoring using two marine fish. Chemosphere 2020, 256, 127202. [CrossRef]

29. Tsangaris, C.; Digka, N.; Valente, T.; Aguilar, A.; Borrell, A.; de Lucia, G.A.; Gambaiani, D.; Garcia-Garin, O.; Kaberi, H.; Martin, J.; et al. Using Boops boops (osteichthyes) to assess microplastic ingestion in the Mediterranean Sea. Mar. Pollut. Bull. 2020, 158, 111397. [CrossRef]

30. Garcia-Garin, O.; Vighi, M.; Aguilar, A.; Tsangaris, C.; Digka, N.; Kaberi, H.; Borrell, A. Boops boops as a bioindicator of microplastic pollution along the Spanish Catalan coast. Mar. Pollut. Bull. 2019, 149, 110648. [CrossRef] 
31. Palazzo, L.; Coppa, S.; Camedda, A.; Cocca, M.; De Falco, F.; Vianello, A.; Massaro, G.; de Lucia, G.A. A novel approach based on multiple fish species and water column compartments in assessing vertical microlitter distribution and composition. Environ. Pollut. 2021, 272, 116419. [CrossRef]

32. Bray, L.; Digka, N.; Tsangaris, C.; Camedda, A.; Gambaiani, D.; de Lucia, G.A.; Matiddi, M.; Miaud, C.; Palazzo, L.; Pérez-delOlmo, A.; et al. Determining suitable fish to monitor plastic ingestion trends in the Mediterranean Sea. Environ. Pollut. 2019, 247, 1071-1077. [CrossRef]

33. Su, L.; Nan, B.; Hassell, K.L.; Craig, N.J.; Pettigrove, V. Microplastics biomonitoring in Australian urban wetlands using a common noxious fish (Gambusia holbrooki). Chemosphere 2019, 228, 65-74. [CrossRef]

34. Bonanno, G.; Orlando-Bonaca, M. Perspectives on using marine species as bioindicators of plastic pollution. Mar. Pollut. Bull. 2018, 137, 209-221. [CrossRef]

35. Jacob, H.; Besson, M.; Swarzenski, P.W.; Lecchini, D.; Metian, M. Effects of Virgin Micro- and Nanoplastics on Fish: Trends, Meta-Analysis, and Perspectives. Environ. Sci. Technol. 2020, 54, 4733-4745. [CrossRef]

36. Karami, A. Gaps in aquatic toxicological studies of microplastics. Chemosphere 2017, 184, 841-848. [CrossRef]

37. Cunningham, E.M.; Sigwart, J.D. Environmentally accurate microplastic levels and their absence from exposure studies. Integr. Comp. Biol. 2019, 59, 1485-1496. [CrossRef]

38. Campanale, C.; Massarelli, C.; Savino, I.; Locaputo, V.; Uricchio, V.F. A detailed review study on potential effects of microplastics and additives of concern on human health. Int. J. Environ. Res. Public Health 2020, 17, 1212. [CrossRef] [PubMed]

39. Chisada, S.; Yoshida, M.; Karita, K. Ingestion of polyethylene microbeads affects the growth and reproduction of medaka, Oryzias latipes. Environ. Pollut. 2019, 254, 113094. [CrossRef]

40. Sathicq, M.B.; Sabatino, R.; Corno, G.; Di Cesare, A. Are microplastic particles a hotspot for the spread and the persistence of antibiotic resistance in aquatic systems? Environ. Pollut. 2021, 279, 116896. [CrossRef] [PubMed]

41. Miao, L.; Wang, P.; Hou, J.; Yao, Y.; Liu, Z.; Liu, S.; Li, T. Distinct community structure and microbial functions of biofilms colonizing microplastics. Sci. Total Environ. 2019, 650, 2395-2402. [CrossRef] [PubMed]

42. Binelli, A.; Pietrelli, L.; Di Vito, S.; Coscia, L.; Sighicelli, M.; Torre, C.D.; Parenti, C.C.; Magni, S. Hazard evaluation of plastic mixtures from four Italian subalpine great lakes on the basis of laboratory exposures of zebra mussels. Sci. Total Environ. 2020, 699, 134366. [CrossRef] [PubMed]

43. Magni, S.; Nigro, L.; Della Torre, C.; Binelli, A. Characterization of plastics and their ecotoxicological effects in the Lambro River (N. Italy). J. Hazard. Mater. 2021, 412, 125204. [CrossRef] [PubMed]

44. Sequeira, I.F.; Prata, J.C.; da Costa, J.P.; Duarte, A.C.; Rocha-Santos, T. Worldwide contamination of fish with microplastics: A brief global overview. Mar. Pollut. Bull. 2020, 160, 111681. [CrossRef]

45. Markic, A.; Gaertner, J.C.; Gaertner-Mazouni, N.; Koelmans, A.A. Plastic ingestion by marine fish in the wild. Crit. Rev. Environ. Sci. Technol. 2020, 50, 657-697. [CrossRef]

46. Fytianos, G.; Ioannidou, E.; Thysiadou, A.; Mitropoulos, A.C.; Kyzas, G.Z. Microplastics in Mediterranean Coastal Countries: A Recent Overview. J. Mar. Sci. Eng. 2021, 9, 98. [CrossRef]

47. Shaikh, I.V.; Shaikh, V.A.E. A comprehensive review on assessment of plastic debris in aquatic environment and its prevalence in fishes and other aquatic animals in India. Sci. Total Environ. 2021, 779, 146421. [CrossRef]

48. Li, Q.; Sun, X. Progress on microplastics research in the Yellow Sea, China. Anthr. Coasts 2020, 3, 43-52. [CrossRef]

49. Barboza, L.G.A.; Lopes, C.; Oliveira, P.; Bessa, F.; Otero, V.; Henriques, B.; Raimundo, J.; Caetano, M.; Vale, C.; Guilhermino, L. Microplastics in wild fish from North East Atlantic Ocean and its potential for causing neurotoxic effects, lipid oxidative damage, and human health risks associated with ingestion exposure. Sci. Total Environ. 2020, 717, 134625. [CrossRef]

50. Gamarro, E.G.; Ryder, J.; Elvevoll, E.O.; Olsen, R.L. Microplastics in Fish and Shellfish-A Threat to Seafood Safety? J. Aquat. Food Prod. Technol. 2020, 29, 417-425. [CrossRef]

51. Thiele, C.J.; Hudson, M.D.; Russell, A.E.; Saluveer, M.; Sidaoui-Haddad, G. Microplastics in fish and fishmeal: An emerging environmental challenge? Sci. Rep. 2021, 11, 1-12. [CrossRef]

52. Wang, W.; Ge, J.; Yu, X. Bioavailability and toxicity of microplastics to fish species: A review. Ecotoxicol. Environ. Saf. 2020, 189, 109913. [CrossRef]

53. Salerno, M.; Berlino, M.; Mangano, M.C.; Sarà, G. Microplastics and the functional traits of fishes: A global meta-analysis. Glob. Chang. Biol. 2021, 27, 2645-2655. [CrossRef] [PubMed]

54. Liu, W.; Zhao, Y.; Shi, Z.; Li, Z.; Liang, X. Ecotoxicoproteomic assessment of microplastics and plastic additives in aquatic organisms: A review. Comp. Biochem. Physiol. Part D Genom. Proteom. 2020, 36, 100713. [CrossRef] [PubMed]

55. Pinheiro, C.; Oliveira, U.; Vieira, N.R. Occurrence and Impacts of Microplastics in Freshwater Fish. J. Aquac. Mar. Biol. 2017, 5. [CrossRef]

56. Collard, F.; Gasperi, J.; Gabrielsen, G.W.; Tassin, B. Plastic Particle Ingestion by Wild Freshwater Fish: A Critical Review. Environ. Sci. Technol. 2019, 53, 12974-12988. [CrossRef]

57. Boerger, C.M.; Lattin, G.L.; Moore, S.L.; Moore, C.J. Plastic ingestion by planktivorous fishes in the North Pacific Central Gyre. Mar. Pollut. Bull. 2010, 60, 2275-2278. [CrossRef]

58. Rochman, C.M.; Hoh, E.; Kurobe, T.; Teh, S.J. Ingested plastic transfers hazardous chemicals to fish and induces hepatic stress. Sci. Rep. 2013, 3, 1-7. [CrossRef] 
59. Sanchez, W.; Bender, C.; Porcher, J.M. Wild gudgeons (Gobio gobio) from French rivers are contaminated by microplastics: Preliminary study and first evidence. Environ. Res. 2014, 128, 98-100. [CrossRef]

60. Parker, B.; Andreou, D.; Green, I.D.; Britton, J.R. Microplastics in freshwater fishes: Occurrence, impacts and future perspectives. Fish Fish. 2021, 22, 467-488. [CrossRef]

61. Adeogun, A.O.; Ibor, O.R.; Khan, E.A.; Chukwuka, A.V.; Omogbemi, E.D.; Arukwe, A. Detection and occurrence of microplastics in the stomach of commercial fish species from a municipal water supply lake in southwestern Nigeria. Environ. Sci. Pollut. Res. 2020, 27, 31035-31045. [CrossRef] [PubMed]

62. Baldwin, A.K.; Spanjer, A.R.; Rosen, M.R.; Thom, T. Microplastics in Lake Mead National Recreation Area, USA: Occurrence and biological uptake. PLoS ONE 2020, 15, e0228896. [CrossRef]

63. Kasamesiri, P.; Thaimuangphol, W. Microplastics ingestion by freshwater fish in the Chi River, Thailand. Int. J. Geomate 2020, 18, 114-119. [CrossRef]

64. Kuśmierek, N.; Popiołek, M. Microplastics in freshwater fish from Central European lowland river (Widawa R., SW Poland). Environ. Sci. Pollut. Res. 2020, 27, 11438-11442. [CrossRef]

65. Frank, Y.A.; Vorobiev, E.D.; Babkina, I.B.; Antsiferov, D.V.; Vorobiev, D.S. Microplastics in fish gut, first records from the Tom River in West Siberia, Russia. Tomsk State Univ. J. Biol. 2020, 130-139. [CrossRef]

66. Urbanski, B.Q.; Denadai, A.C.; Azevedo-Santos, V.M.; Nogueira, M.G. First record of plastic ingestion by an important commercial native fish (Prochilodus lineatus) in the middle Tietê River basin, Southeast Brazil. Biota Neotrop. 2020, 20. [CrossRef]

67. Roch, S.; Walter, T.; Ittner, L.D.; Friedrich, C.; Brinker, A. A systematic study of the microplastic burden in freshwater fishes of south-western Germany-Are we searching at the right scale? Sci. Total Environ. 2019, 689, 1001-1011. [CrossRef]

68. Ryan, M.; Watkins, L.; Walter, M. Hudson River juvenile Blueback herring avoid ingesting microplastics. Mar. Pollut. Bull. 2019, 146, 935-939. [CrossRef] [PubMed]

69. Pazos, R.S.; Maiztegui, T.; Colautti, D.C.; Paracampo, A.H.; Gómez, N. Microplastics in gut contents of coastal freshwater fish from Río de la Plata estuary. Mar. Pollut. Bull. 2017, 122, 85-90. [CrossRef]

70. Campbell, S.H.; Williamson, P.R.; Hall, B.D. Microplastics in the gastrointestinal tracts of fish and the water from an urban prairie creek. Facets 2017, 2, 395-409. [CrossRef]

71. Garcia, F.; De Carvalho, A.R.; Riem-Galliano, L.; Tudesque, L.; Albignac, M.; Ter Halle, A.; Cucherousset, J. Stable Isotope Insights into Microplastic Contamination within Freshwater Food Webs. Environ. Sci. Technol. 2021, 55, 1024-1035. [CrossRef]

72. Silva-Cavalcanti, J.S.; Silva, J.D.B.; de França, E.J.; de Araújo, M.C.B.; Gusmão, F. Microplastics ingestion by a common tropical freshwater fishing resource. Environ. Pollut. 2017, 221, 218-226. [CrossRef]

73. Peters, C.A.; Bratton, S.P. Urbanization is a major influence on microplastic ingestion by sunfish in the Brazos River Basin, Central Texas, USA. Environ. Pollut. 2016, 210, 380-387. [CrossRef] [PubMed]

74. Faure, F.; Corbaz, M.; Baecher, H.; De Alencastro, L.F. Pollution due to plastics and microplastics in lake Geneva and in the Mediterranean sea. Arch. Sci. 2012, 65, 157-164. [CrossRef]

75. de Oliveira, J.C.D.; de Oliveira, J.F.; de Oliveira Marques, A.; Peretti, D.; da Costa, R.S.; Novaes, J.L.C. Trophic ecology of detritivorous fish along a reservoir cascade in a tropical semi-arid region. Ecol. Freshw. Fish 2021, 30, 234-243. [CrossRef]

76. Taghizadeh Rahmat Abadi, Z.; Abtahi, B.; Grossart, H.-P.; Khodabandeh, S. Microplastic content of Kutum fish, Rutilus frisii kutum in the southern Caspian Sea. Sci. Total Environ. 2021, 752, 141542. [CrossRef]

77. Talley, T.S.; Venuti, N.; Whelan, R. Natural history matters: Plastics in estuarine fish and sediments at the mouth of an urban watershed. PLoS ONE 2020, 15, e0229777. [CrossRef]

78. Ferreira, G.V.B.; Barletta, M.; Lima, A.R.A. Use of estuarine resources by top predator fishes. How do ecological patterns affect rates of contamination by microplastics? Sci. Total Environ. 2019, 655, 292-304. [CrossRef] [PubMed]

79. Silva, J.D.B.; Barletta, M.; Lima, A.R.A.; Ferreira, G.V.B. Use of resources and microplastic contamination throughout the life cycle of grunts (Haemulidae) in a tropical estuary. Environ. Pollut. 2018, 242, 1010-1021. [CrossRef]

80. Ferreira, G.V.B.; Barletta, M.; Lima, A.R.A.; Dantas, D.V.; Justino, A.K.S.; Costa, M.F. Plastic debris contamination in the life cycle of Acoupa weakfish (Cynoscion acoupa) in a tropical estuary. ICES J. Mar. Sci. 2016, 73, 2695-2707. [CrossRef]

81. Naidoo, T.; Smit, A.J.; Glassom, D. Plastic ingestion by estuarine mullet Mugil cephalus (Mugilidae) in an urban harbour, KwaZulu-Natal, South Africa. Afr. J. Mar. Sci. 2016, 38, 145-149. [CrossRef]

82. Kasamesiri, P.; Meksumpun, C.; Meksumpun, S.; Ruengsorn, C. Assessment on microplastics contamination in freshwater fish: A case study of the Ubolratana Reservoir, Thailand. Int. J. Geomate 2021, 20, 62-68. [CrossRef]

83. Ramos, J.A.A.; Barletta, M.; Costa, M.F. Ingestion of nylon threads by Gerreidae while using a tropical estuary as foraging grounds. Aquat. Biol. 2012, 17, 29-34. [CrossRef]

84. Possatto, F.E.; Barletta, M.; Costa, M.F.; Ivar do Sul, J.A.; Dantas, D.V. Plastic debris ingestion by marine catfish: An unexpected fisheries impact. Mar. Pollut. Bull. 2011, 62, 1098-1102. [CrossRef]

85. Sun, D.; Wang, J.; Xie, S.; Tang, H.; Zhang, C.; Xu, G.; Zou, J.; Zhou, A. Characterization and spatial distribution of microplastics in two wild captured economic freshwater fish from north and west rivers of Guangdong province. Ecotoxicol. Environ. Saf. 2021, 207, 111555. [CrossRef] [PubMed]

86. Ribeiro-Brasil, D.R.G.; Torres, N.R.; Picanço, A.B.; Sousa, D.S.; Ribeiro, V.S.; Brasil, L.S.; de Assis Montag, L.F. Contamination of stream fish by plastic waste in the Brazilian Amazon. Environ. Pollut. 2020, 266, 115241. [CrossRef] [PubMed] 
87. Wang, S.; Zhang, C.; Pan, Z.; Sun, D.; Zhou, A.; Xie, S.; Wang, J.; Zou, J. Microplastics in wild freshwater fish of different feeding habits from Beijiang and Pearl River Delta regions, south China. Chemosphere 2020, 258, 127345. [CrossRef]

88. Rodríguez-Sierra, C.M.; Antón-Pardo, M.; Quintana, X.D.; Armengol, X. Microplastics ingestion by the exotic fish Gambusia holbrooki in two Mediterranean coastal lagoons. Ecosistemas 2020, 29, 2097. [CrossRef]

89. Adu-Boahen, K.; Dadson, I.Y.; Mensah, D.K.D.; Kyeremeh, S. Mapping ecological impact of microplastics on freshwater habitat in the central region of Ghana: A case study of River Akora. GeoJournal 2020. [CrossRef]

90. Garcia, T.D.; Cardozo, A.L.P.; Quirino, B.A.; Yofukuji, K.Y.; Ganassin, M.J.M.; dos Santos, N.C.L.; Fugi, R. Ingestion of Microplastic by Fish of Different Feeding Habits in Urbanized and Non-urbanized Streams in Southern Brazil. Water Air Soil Pollut. 2020, 231, 1-11. [CrossRef]

91. Li, Y.; Chen, G.; Xu, K.; Huang, K.; Wang, J. Microplastics environmental effect and risk assessment on the aquaculture systems from South China. Int. J. Environ. Res. Public Health 2021, 18, 1869. [CrossRef]

92. Park, T.-J.; Lee, S.-H.; Lee, M.-S.; Lee, J.-K.; Lee, S.-H.; Zoh, K.-D. Occurrence of microplastics in the Han River and riverine fish in South Korea. Sci. Total Environ. 2020, 708, 134535. [CrossRef]

93. Park, T.-J.; Lee, S.-H.; Lee, M.-S.; Lee, J.-K.; Park, J.-H.; Zoh, K.-D. Distributions of microplastics in surface water, fish, and sediment in the vicinity of a sewage treatment plant. Water 2020, 12, 3333. [CrossRef]

94. Blettler, M.C.M.; Garello, N.; Ginon, L.; Abrial, E.; Espinola, L.A.; Wantzen, K.M. Massive plastic pollution in a mega-river of a developing country: Sediment deposition and ingestion by fish (Prochilodus lineatus). Environ. Pollut. 2019, 255, 113348. [CrossRef] [PubMed]

95. Yuan, W.; Liu, X.; Wang, W.; Di, M.; Wang, J. Microplastic abundance, distribution and composition in water, sediments, and wild fish from Poyang Lake, China. Ecotoxicol. Environ. Saf. 2019, 170, 180-187. [CrossRef] [PubMed]

96. Jabeen, K.; Su, L.; Li, J.; Yang, D.; Tong, C.; Mu, J.; Shi, H. Microplastics and mesoplastics in fish from coastal and fresh waters of China. Environ. Pollut. 2017, 221, 141-149. [CrossRef] [PubMed]

97. Andrade, M.C.; Winemiller, K.O.; Barbosa, P.S.; Fortunati, A.; Chelazzi, D.; Cincinelli, A.; Giarrizzo, T. First account of plastic pollution impacting freshwater fishes in the Amazon: Ingestion of plastic debris by piranhas and other serrasalmids with diverse feeding habits. Environ. Pollut. 2019, 244, 766-773. [CrossRef]

98. Biginagwa, F.J.; Mayoma, B.S.; Shashoua, Y.; Syberg, K.; Khan, F.R. First evidence of microplastics in the African Great Lakes: Recovery from Lake Victoria Nile perch and Nile tilapia. J. Great Lakes Res. 2016, 42, 146-149. [CrossRef]

99. Collard, F.; Gasperi, J.; Gilbert, B.; Eppe, G.; Azimi, S.; Rocher, V.; Tassin, B. Anthropogenic particles in the stomach contents and liver of the freshwater fish Squalius cephalus. Sci. Total Environ. 2018, 643, 1257-1264. [CrossRef] [PubMed]

100. Devi, S.S.; Sreedevi, A.V.; Kumar, A.B. First report of microplastic ingestion by the alien fish Pirapitinga (Piaractus brachypomus) in the Ramsar site Vembanad Lake, south India. Mar. Pollut. Bull. 2020, 160, 111637. [CrossRef] [PubMed]

101. Faure, F.; Demars, C.; Wieser, O.; Kunz, M.; De Alencastro, L.F. Plastic pollution in Swiss surface waters: Nature and concentrations, interaction with pollutants. Environ. Chem. 2015, 12, 582-591. [CrossRef]

102. Lima, F.P.; Azevedo-Santos, V.M.; Santos, V.M.R.; Vidotto-Magnoni, A.P.; Soares, C.L.; Manzano, F.V.; Nobile, A.B. Plastic Ingestion by Commercial and Non-Commercial Fishes from a Neotropical River Basin. Water Air Soil Pollut. 2021, 232, 29. [CrossRef]

103. Slootmaekers, B.; Catarci Carteny, C.; Belpaire, C.; Saverwyns, S.; Fremout, W.; Blust, R.; Bervoets, L. Microplastic contamination in gudgeons (Gobio gobio) from Flemish rivers (Belgium). Environ. Pollut. 2019, 244, 675-684. [CrossRef]

104. Garcia, A.G.; Suárez, D.C.; Li, J.; Rotchell, J.M. A comparison of microplastic contamination in freshwater fish from natural and farmed sources. Environ. Sci. Pollut. Res. 2021, 28, 14488-14497. [CrossRef] [PubMed]

105. Cordova, M.R.; Riani, E.; Shiomoto, A. Microplastics ingestion by blue panchax fish (Aplocheilus sp.) from Ciliwung Estuary, Jakarta, Indonesia. Mar. Pollut. Bull. 2020, 161, 111763. [CrossRef]

106. O'Connor, J.D.; Mahon, A.M.; Ramsperger, A.F.R.M.; Trotter, B.; Redondo-Hasselerharm, P.E.; Koelmans, A.A.; Lally, H.T.; Murphy, S. Microplastics in Freshwater Biota: A Critical Review of Isolation, Characterization, and Assessment Methods. Glob. Chall. 2020, 4, 1800118. [CrossRef]

107. Naidoo, T.; Sershen; Thompson, R.C.; Rajkaran, A. Quantification and characterisation of microplastics ingested by selected juvenile fish species associated with mangroves in KwaZulu-Natal, South Africa. Environ. Pollut. 2020, 257, 113635. [CrossRef] [PubMed]

108. Lin, L.; Ma, L.S.; Li, H.X.; Pan, Y.F.; Liu, S.; Zhang, L.; Peng, J.P.; Fok, L.; Xu, X.R.; He, W.H. Low level of microplastic contamination in wild fish from an urban estuary. Mar. Pollut. Bull. 2020, 160, 111650. [CrossRef]

109. Martinez-Tavera, E.; Duarte-Moro, A.M.; Sujitha, S.B.; Rodriguez-Espinosa, P.F.; Rosano-Ortega, G.; Expósito, N. Microplastics and metal burdens in freshwater Tilapia (Oreochromis niloticus) of a metropolitan reservoir in Central Mexico: Potential threats for human health. Chemosphere 2021, 266, 128968. [CrossRef] [PubMed]

110. Tien, C.J.; Wang, Z.X.; Chen, C.S. Microplastics in water, sediment and fish from the Fengshan River system: Relationship to aquatic factors and accumulation of polycyclic aromatic hydrocarbons by fish. Environ. Pollut. 2020, 265, 114962. [CrossRef]

111. McNeish, R.E.; Kim, L.H.; Barrett, H.A.; Mason, S.A.; Kelly, J.J.; Hoellein, T.J. Microplastic in riverine fish is connected to species traits. Sci. Rep. 2018, 8, 11639. [CrossRef]

112. Galafassi, S.; Sighicelli, M.; Pusceddu, A.; Bettinetti, R.; Cau, A.; Temperini, M.E.; Gillibert, R.; Ortolani, M.; Pietrelli, L.; Zaupa, S.; et al. Microplastic pollution in perch (Perca fluviatilis, Linnaeus 1758) from Italian south-alpine lakes. Environ. Pollut. 2021, 288, 117782. [CrossRef] 
113. Zhang, L.; Xie, Y.; Zhong, S.; Liu, J.; Qin, Y.; Gao, P. Microplastics in freshwater and wild fishes from Lijiang River in Guangxi, Southwest China. Sci. Total Environ. 2021, 755, 142428. [CrossRef] [PubMed]

114. Driscoll, S.C.; Glassic, H.C.; Guy, C.S.; Koel, T.M. Presence of microplastics in the food web of the largest high-elevation lake in North America. Water 2021, 13, 264. [CrossRef]

115. Maghsodian, Z.; Sanati, A.M.; Ramavandi, B.; Ghasemi, A.; Sorial, G.A. Microplastics accumulation in sediments and Periophthalmus waltoni fish, mangrove forests in southern Iran. Chemosphere 2021, 264, 128543. [CrossRef]

116. Bosshart, S.; Erni-Cassola, G.; Burkhardt-Holm, P. Independence of microplastic ingestion from environmental load in the round goby (Neogobius melanostomus) from the Rhine river using high quality standards. Environ. Pollut. 2020, 267, 115664. [CrossRef] [PubMed]

117. Merga, L.B.; Redondo-Hasselerharm, P.E.; Van den Brink, P.J.; Koelmans, A.A. Distribution of microplastic and small macroplastic particles across four fish species and sediment in an African lake. Sci. Total Environ. 2020, 741, 140527. [CrossRef]

118. Lv, W.; Yuan, Q.; He, D.; Lv, W.; Zhou, W. Microplastic contamination caused by different rearing modes of Asian swamp eel (Monopterus albus). Aquac. Res. 2020, 51, 5084-5095. [CrossRef]

119. Khan, F.R.; Shashoua, Y.; Crawford, A.; Drury, A.; Sheppard, K.; Stewart, K.; Sculthorp, T. 'The Plastic Nile': First Evidence of Microplastic Contamination in Fish from the Nile River (Cairo, Egypt). Toxics 2020, 8, 22. [CrossRef]

120. Li, B.; Su, L.; Zhang, H.; Deng, H.; Chen, Q.; Shi, H. Microplastics in fishes and their living environments surrounding a plastic production area. Sci. Total Environ. 2020, 727, 138662. [CrossRef]

121. Sembiring, E.; Fareza, A.A.; Suendo, V.; Reza, M. The Presence of Microplastics in Water, Sediment, and Milkfish (Chanos chanos) at the Downstream Area of Citarum River, Indonesia. Water Air Soil Pollut. 2020, 231, 1-14. [CrossRef]

122. Suresh, A.; Vijayaraghavan, G.; Saranya, K.S.; Neethu, K.V.; Aneesh, B.; Bijoy Nandan, S. Microplastics distribution and contamination from the Cochin coastal zone, India. Reg. Stud. Mar. Sci. 2020, 40, 101533. [CrossRef]

123. Garcés-Ordóñez, O.; Mejía-Esquivia, K.A.; Sierra-Labastidas, T.; Patiño, A.; Blandón, L.M.; Espinosa Díaz, L.F. Prevalence of microplastic contamination in the digestive tract of fishes from mangrove ecosystem in Cispata, Colombian Caribbean. Mar. Pollut. Bull. 2020, 154, 111085. [CrossRef]

124. Huang, J.S.; Koongolla, J.B.; Li, H.X.; Lin, L.; Pan, Y.F.; Liu, S.; He, W.H.; Maharana, D.; Xu, X.R. Microplastic accumulation in fish from Zhanjiang mangrove wetland, South China. Sci. Total Environ. 2020, 708, 134839. [CrossRef]

125. Lv, W.; Zhou, W.; Lu, S.; Huang, W.; Yuan, Q.; Tian, M.; Lv, W.; He, D. Microplastic pollution in rice-fish co-culture system: A report of three farmland stations in Shanghai, China. Sci. Total Environ. 2019, 652, 1209-1218. [CrossRef] [PubMed]

126. Zheng, K.; Fan, Y.; Zhu, Z.; Chen, G.; Tang, C.; Peng, X. Occurrence and Species-Specific Distribution of Plastic Debris in Wild Freshwater Fish from the Pearl River Catchment, China. Environ. Toxicol. Chem. 2019, 38, 1504-1513. [CrossRef]

127. Wagner, J.; Wang, Z.-M.; Ghosal, S.; Murphy, M.; Wall, S.; Cook, A.-M.; Robberson, W.; Allen, H. Nondestructive Extraction and Identification of Microplastics from Freshwater Sport Fish Stomachs. Environ. Sci. Technol. 2019, 53, 14496-14506. [CrossRef] [PubMed]

128. Calderon, E.A.; Hansen, P.; Rodríguez, A.; Blettler, M.C.M.; Syberg, K.; Khan, F.R. Microplastics in the Digestive Tracts of Four Fish Species from the Ciénaga Grande de Santa Marta Estuary in Colombia. Water Air Soil Pollut. 2019, 230, 257. [CrossRef]

129. Su, L.; Deng, H.; Li, B.; Chen, Q.; Pettigrove, V.; Wu, C.; Shi, H. The occurrence of microplastic in specific organs in commercially caught fishes from coast and estuary area of east China. J. Hazard. Mater. 2019, 365, 716-724. [CrossRef] [PubMed]

130. Xiong, X.; Zhang, K.; Chen, X.; Shi, H.; Luo, Z.; Wu, C. Sources and distribution of microplastics in China's largest inland lake-Qinghai Lake. Environ. Pollut. 2018, 235, 899-906. [CrossRef]

131. Horton, A.A.; Jürgens, M.D.; Lahive, E.; van Bodegom, P.M.; Vijver, M.G. The influence of exposure and physiology on microplastic ingestion by the freshwater fish Rutilus rutilus (roach) in the River Thames, UK. Environ. Pollut. 2018, 236, 188-194. [CrossRef]

132. Bessa, F.; Barría, P.; Neto, J.M.; Frias, J.P.G.L.; Otero, V.; Sobral, P.; Marques, J.C. Occurrence of microplastics in commercial fish from a natural estuarine environment. Mar. Pollut. Bull. 2018, 128, 575-584. [CrossRef]

133. Pegado, S.; de Souza, T.; Schmid, K.; Winemiller, K.O.; Chelazzi, D.; Cincinelli, A.; Dei, L.; Giarrizzo, T. First evidence of microplastic ingestion by fishes from the Amazon River estuary. Mar. Pollut. Bull. 2018, 133, 814-821. [CrossRef]

134. Karlsson, T.M.; Vethaak, A.D.; Almroth, B.C.; Ariese, F.; van Velzen, M.; Hassellöv, M.; Leslie, H.A. Screening for microplastics in sediment, water, marine invertebrates and fish: Method development and microplastic accumulation. Mar. Pollut. Bull. 2017, 122, 403-408. [CrossRef] [PubMed]

135. Zhang, K.; Xiong, X.; Hu, H.; Wu, C.; Bi, Y.; Wu, Y.; Zhou, B.; Lam, P.K.S.; Liu, J. Occurrence and Characteristics of Microplastic Pollution in Xiangxi Bay of Three Gorges Reservoir, China. Environ. Sci. Technol. 2017, 51, 3794-3801. [CrossRef]

136. Mcgoran, A.R.; Clark, P.F.; Morritt, D. Presence of microplastic in the digestive tracts of European flounder, Platichthys flesus, and European smelt, Osmerus eperlanus, from the River Thames. Environ. Pollut. 2017, 220, 744-751. [CrossRef]

137. Romeo, T.; Pietro, B.; Pedà, C.; Consoli, P.; Andaloro, F.; Fossi, M.C. First evidence of presence of plastic debris in stomach of large pelagic fish in the Mediterranean Sea. Mar. Pollut. Bull. 2015, 95, 358-361. [CrossRef] [PubMed]

138. Cannon, S.M.E.; Lavers, J.L.; Figueiredo, B. Plastic ingestion by fish in the Southern Hemisphere: A baseline study and review of methods. Mar. Pollut. Bull. 2016, 107, 286-291. [CrossRef]

139. Jovanović, B. Ingestion of microplastics by fish and its potential consequences from a physical perspective. Integr. Environ. Assess. Manag. 2017, 13, 510-515. [CrossRef] [PubMed] 
140. Abbasi, S.; Soltani, N.; Keshavarzi, B.; Moore, F.; Turner, A.; Hassanaghaei, M. Microplastics in different tissues of fish and prawn from the Musa Estuary, Persian Gulf. Chemosphere 2018, 205, 80-87. [CrossRef]

141. Kim, S.W.; Chae, Y.; Kim, D.; An, Y.J. Zebrafish can recognize microplastics as inedible materials: Quantitative evidence of ingestion behavior. Sci. Total Environ. 2019, 649, 156-162. [CrossRef]

142. Khosrovyan, A.; Gabrielyan, B.; Kahru, A. Ingestion and effects of virgin polyamide microplastics on Chironomus riparius adult larvae and adult zebrafish Danio rerio. Chemosphere 2020, 259, 127456. [CrossRef]

143. de Sá, L.C.; Luís, L.G.; Guilhermino, L. Effects of microplastics on juveniles of the common goby (Pomatoschistus microps): Confusion with prey, reduction of the predatory performance and efficiency, and possible influence of developmental conditions. Environ. Pollut. 2015, 196, 359-362. [CrossRef]

144. Lusher, A.L.; McHugh, M.; Thompson, R.C. Occurrence of microplastics in the gastrointestinal tract of pelagic and demersal fish from the English Channel. Mar. Pollut. Bull. 2013, 67, 94-99. [CrossRef]

145. Miranda, T.; Vieira, L.R.; Guilhermino, L. Neurotoxicity, behavior, and lethal effects of cadmium, microplastics, and their mixtures on Pomatoschistus microps juveniles from two wild populations exposed under laboratory conditions-implications to environmental and human risk assessment. Int. J. Environ. Res. Public Health 2019, 16, 2857. [CrossRef]

146. Yin, L.; Chen, B.; Xia, B.; Shi, X.; Qu, K. Polystyrene microplastics alter the behavior, energy reserve and nutritional composition of marine jacopever (Sebastes schlegelii). J. Hazard. Mater. 2018, 360, 97-105. [CrossRef] [PubMed]

147. Jin, Y.; Xia, J.; Pan, Z.; Yang, J.; Wang, W.; Fu, Z. Polystyrene microplastics induce microbiota dysbiosis and inflammation in the gut of adult zebrafish. Environ. Pollut. 2018, 235, 322-329. [CrossRef] [PubMed]

148. Lu, Y.; Zhang, Y.; Deng, Y.; Jiang, W.; Zhao, Y.; Geng, J.; Ding, L.; Ren, H. Uptake and Accumulation of Polystyrene Microplastics in Zebrafish (Danio rerio) and Toxic Effects in Liver. Environ. Sci. Technol. 2016, 50, 4054-4060. [CrossRef] [PubMed]

149. Mattsson, K.; Ekvall, M.T.; Hansson, L.A.; Linse, S.; Malmendal, A.; Cedervall, T. Altered behavior, physiology, and metabolism in fish exposed to polystyrene nanoparticles. Environ. Sci. Technol. 2015, 49, 553-561. [CrossRef] [PubMed]

150. Greven, A.C.; Merk, T.; Karagöz, F.; Mohr, K.; Klapper, M.; Jovanović, B.; Palić, D. Polycarbonate and polystyrene nanoplastic particles act as stressors to the innate immune system of fathead minnow (Pimephales promelas). Environ. Toxicol. Chem. 2016, 35, 3093-3100. [CrossRef] 